\title{
1. DEEP SEA DRILLING PROJECT LEG 60: CRUISE OBJECTIVES, PRINCIPAL RESULTS, AND EXPLANATORY NOTES ${ }^{1}$
}

\author{
D. M. Hussong, ${ }^{2}$ S. Uyeda,${ }^{3}$ R. Knapp,${ }^{4}$ H. Ellis, ${ }^{5}$ S. Kling, ${ }^{6}$ and J. Natland ${ }^{4}$
}

\section{OBJECTIVES OF LEG 60}

A major goal of DSDP sampling of tectonically active ocean margins has been to obtain a complete transect of an interoceanic subduction zone-island arcback-arc basin system. A classic example of such a system is in the western Pacific, where an apparent series of back-arc basins and volcanic arcs have formed behind (west of) the Mariana Trench. Two consecutive drilling legs (Legs 59 and 60) were assigned to drill an east-west transect of sites along latitude $18^{\circ} \mathrm{N}$, from the Mariana Basin of the Pacific Ocean to the oldest inactive island arcs and back-arc spreading basins of the Philippine Sea. The western (older, inactive) half of this transect (Philippine Sea, Palau-Kyushu Ridge, Parece Vela Basin, and the West Mariana Ridge-Sites 447451) was drilled during Leg 59. The objective of Leg 60 was to sample the tectonically active eastern portion of the transect in a closely spaced series of holes (Fig. 1 and Table 1) across the presently opening back-arc basin (Mariana Trough, Site Survey Target SP-4, Sites 453456), the Mariana arc itself (Site Survey Target SP-3b; Site 457), the Mariana fore-arc region (Site Survey Target SP-3; Sites 458 and 459), and deep within the Mariana Trench (Site Survey Target SP-2; Sites 460 and 461). In addition, one site (Site Survey Target SP-1, Site 452) was drilled on the Pacific plate seaward of the trench to obtain a reference section of sediments and oceanic crust being delivered to the trench. Although even this geographical concentration of drill sites provided sparse data in the complex arc-trench system, it was hoped that by drilling each of the primary structural elements of the area we could elucidate the spreading, subsidence, and sedimentation history of the Mariana Trough, the volcanic and tectonic history of the Mariana arc, and the tectonic history of the trench and fore-arc region. Because of the emphasis on investigating the youngest and most active portions of the transect during Leg 60, the Glomar Challenger was equipped with logging, electrical resistivity, and downhole heat flow instruments to obtain in situ data on the physical and thermal state of recently formed and actively deforming trench, arc, and interarc basin crust.

\footnotetext{
1 Initial Reports of the Deep Sea Drilling Project, Volume 60.

2 Hawaii Institute of Geophysics, Honolulu, Hawaii.

3 Earthquake Research Institute, University of Tokyo, Tokyo, Japan.

4 Deep Sea Drilling Project, Scripps Institution of Oceanography, La Jolla, California

5 Marathon Oil Company, Denver Research Center, Littleton, Colorado.

6 Marine Life Research Group, Scripps Institution of Oceanography, La Jolla, California (present address: 416 Shore View Lane, Leucadia, California).
}

\section{PRINCIPAL RESULTS}

\section{Pacific Plate}

Site $\mathbf{4 5 2}$ was planned as a Pacific plate reference section to identify old ocean basin sediments and rocks which our later drilling might uncover in the inner (western) trench wall. At two holes at this site, we encountered hard impenetrable cherts of probable Campanian age after coring only a few tens of meters of mixed Neogene pelagic sediments. These thin Neogene sediments gave insufficient support to the drill collars to allow spudding into the chert. The site, one of 16 in the far western Pacific with a profound Cretaceous-Neogene disconformity, established that only a very trivial, if any, post-Cretaceous pelagic sediment component from the oceanic side would be expected to be accreted to the inner Mariana Trench wall.

\section{Mariana Trough}

To test the rate and geometry of back-arc basin opening and the evolution of the new crust formed during opening, we planned one hole in the supposedly oldest part of the trough on the west side, one hole near the center on very young crust, and one hole through the Mariana arc sediment apron on the east side of the trough (Fig. 2). If Mariana Trough spreading is symmetric, then the eastern site should be of intermediate crustal age.

Our first attempt at the eastern side of the Mariana Trough proved unsuccessful (coarse sandy turbidites caved into the hole at Site 455 after only $104 \mathrm{~m}$ of penetration), so we shifted this target to another site on the distal edge of the volcaniclastic sediment apron, nearer the center of the trough. Drilling at this revised target, Site 456 , was successful, as were the other back-arc basin sites.

At all three of the successful sites (Sites 453, 454, and 456), turbiditic sequences of volcaniclastic sediments derived from the Mariana Arc overlie igneous and metamorphic rocks (Fig. 3). At all three sites the sediments contain substantial hemipelagic and biogenic components. Furthermore, all sites have a transition midway through the Pleistocene from non-siliceous sediments low in $\mathrm{CaCO}_{3}$, indicating sedimentation very close to the carbonate compensation depth, to overlying siliceous oozes. At Site 453, the westernmost site, more recent sediments have a decreasing volcaniclastic component. We attribute this change to the site's increasing distance from the arc volcanoes as the trough opened. The ages of the oldest cored sediments, bathymetric 


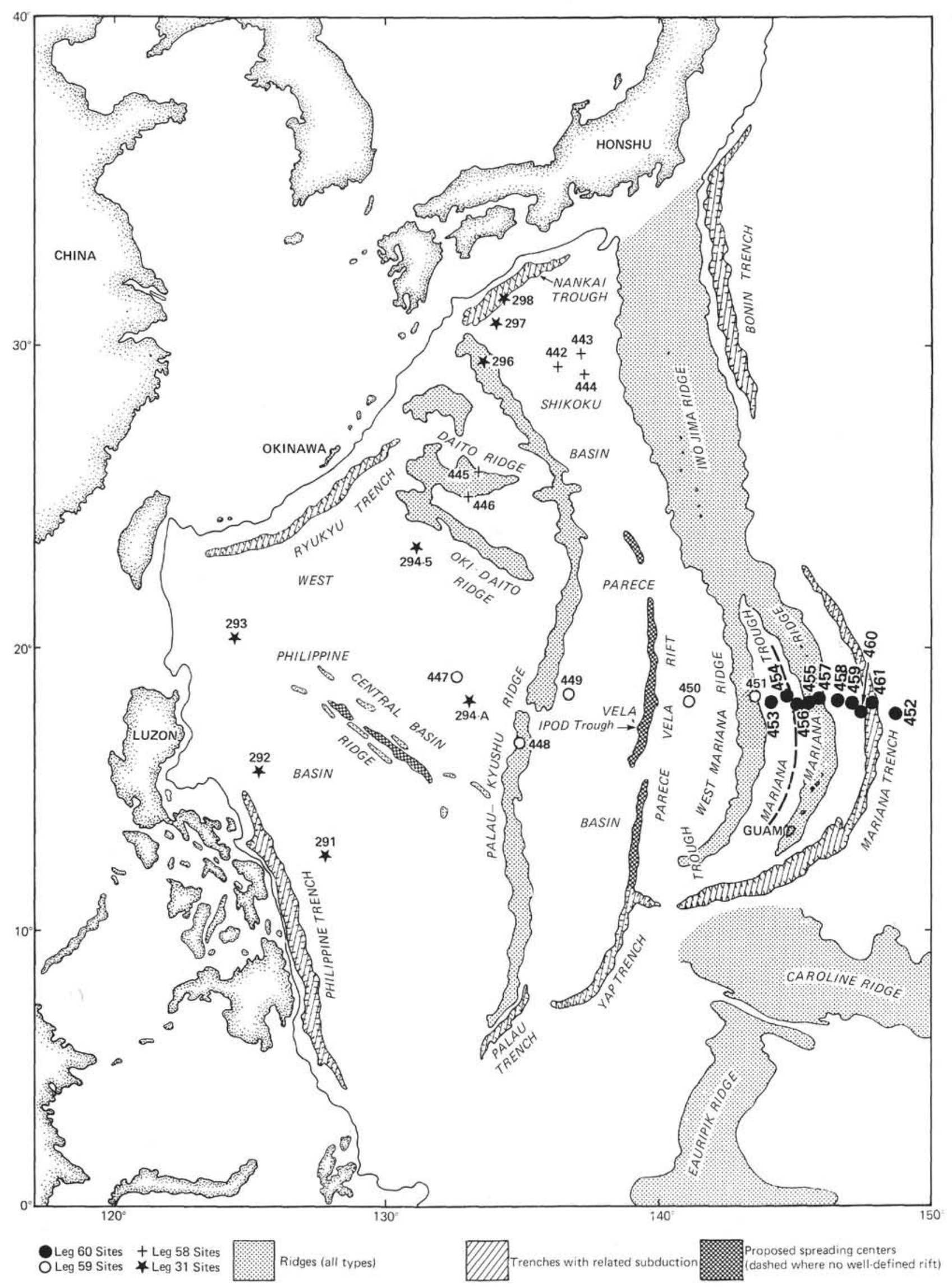

Figure 1. Location of sites drilled on Leg $60(\bullet)$, Leg $59(\mathrm{O})$, Leg $58(+)$, and Leg $31(\star)$ in the Philippine Sea. 
Table 1. Leg 60 coring summary.

\begin{tabular}{|c|c|c|c|c|c|c|c|c|c|c|}
\hline $\begin{array}{l}\text { IPOD } \\
\text { Site } \\
\text { Survey } \\
\text { Target }\end{array}$ & Hole & $\begin{array}{l}\text { Dates } \\
\text { (1978) }\end{array}$ & $\begin{array}{l}\text { Latitude } \\
\text { (N) }\end{array}$ & $\begin{array}{l}\text { Longitude } \\
\text { (E) }\end{array}$ & $\begin{array}{l}\text { Water } \\
\text { Depth } \\
\text { (m) }\end{array}$ & $\begin{array}{l}\text { Penetration } \\
\text { (m) }\end{array}$ & $\begin{array}{c}\text { No. } \\
\text { of } \\
\text { Cores }\end{array}$ & $\begin{array}{l}\text { Length } \\
\text { Cored } \\
\text { (m) }\end{array}$ & $\begin{array}{l}\text { Length } \\
\text { Recovered } \\
\text { (m) }\end{array}$ & $\begin{array}{c}\text { Recovery } \\
(\%)\end{array}$ \\
\hline SP-1 & 452 & 23-24 March & $17^{\circ} 40.19^{\prime}$ & $148^{\circ} 37.73^{\prime}$ & 5858 & 28.0 & 3 & 28.0 & 27.35 & 97.7 \\
\hline SP-1 & $452 \mathrm{~A}$ & 24-27 March & $17^{\circ} 40.17^{\prime}$ & $148^{\circ} 37.75^{\prime}$ & 5862.5 & 46.5 & 5 & 46.5 & 21.72 & 46.7 \\
\hline$S P-4 F$ & 453 & $28 \mathrm{March}-4$ April & $17^{\circ} 54.42^{\prime}$ & $143^{\circ} 40.95^{\prime}$ & 4693 & 605.0 & 64 & 605.0 & 236.83 & 39.1 \\
\hline SP-4E & 454 & 5 April & $18^{\circ} 00.78^{\prime}$ & $144^{\circ} 31.92^{\prime}$ & 3818.5 & 38.5 & 5 & 38.5 & 22.51 & 58,4 \\
\hline SP $-4 E$ & $454 \mathrm{~A}$ & 6-9 April & $18^{\circ} 00.78^{\prime}$ & $144^{\circ} 31^{\prime} .92^{\prime}$ & 3819 & 171.5 & 16 & 142.5 & 40.92 & 28.7 \\
\hline$S P-4 D$ & 455 & 10-11 April & $17^{\circ} 51.26^{\prime}$ & $145^{\circ} 21.48^{\prime}$ & 3468 & 104.0 & 11 & 104.0 & 31.28 & 30.0 \\
\hline SP.4D & 456 & 12-13 April & $17^{\circ} 54.68^{\prime}$ & $145^{\circ} 10.77^{\prime}$ & 3590.5 & 169.0 & 19 & 169.0 & 32.23 & 19.0 \\
\hline$S P-4 D$ & $456 \mathrm{~A}$ & 14-16 April & $17^{\circ} 54.71^{\prime}$ & $145^{\circ} 10.88^{\prime}$ & 3591 & 159.0 & 15 & 140.0 & 37.75 & 26.9 \\
\hline SP-3B & 457 & 16-17 April & $17^{\circ} 49.99^{\prime}$ & $145^{\circ} 49.02^{\prime}$ & 2637 & 61.0 & 6 & 51.5 & 19.42 & 37.5 \\
\hline$S P-3 C$ & 458 & 18-22 April & $17^{\circ} 51.84^{\prime}$ & $146^{\circ} 56.06^{\prime}$ & 3449 & 465.5 & 49 & 465.5 & 97.83 & 21.0 \\
\hline SP-3C & 459 & 25-26 April & $17^{\circ} 51.75^{\prime}$ & $147^{\circ} 18.09^{\prime}$ & 4130 & 3.5 & 1 & 3.5 & 3.28 & 94.0 \\
\hline SP-3C & $459 \mathrm{~A}$ & 26 April & $17^{\circ} 51.75^{\prime}$ & $147^{\circ} 18.09^{\prime}$ & 4120 & 67.0 & 0 & - & - & - \\
\hline SP-3C & $459 \mathrm{~B}$ & 26 April-4 May & $17^{\circ} 51.75^{\prime}$ & $147^{\circ} 18.09^{\prime}$ & 4115 & 691.5 & 73 & 691.5 & 182.14 & 26.0 \\
\hline SP-2B & 460 & 5-6 May & $17^{\circ} 40.14^{\prime}$ & $147^{\circ} 35.92^{\circ}$ & 6451 & 85.0 & 9 & 85.0 & 27.21 & 32.0 \\
\hline SP.2B & $460 \mathrm{~A}$ & 7-9 May & $17^{\circ} 40.02^{\prime}$ & $147^{\circ} 35.16^{\prime}$ & 6443 & 99.5 & 11 & 99.5 & 36.68 & 36.8 \\
\hline SP-2B & 461 & 10-11 May & $17^{\circ} 46.05^{\prime}$ & $147^{\circ} 41.18^{\prime}$ & 7029 & 20.5 & 3 & 20.5 & 8.62 & 42.0 \\
\hline \multirow[t]{2}{*}{ SP-2B } & $461 \mathrm{~A}$ & 11 May & $17^{\circ} 46.01^{\prime}$ & $147^{\circ} 41.26^{\prime}$ & 7034 & 15.5 & 2 & 15.5 & 7.26 & 46.8 \\
\hline & & & & & & & 292 & 2706.0 & 833.01 & 30.8 \\
\hline
\end{tabular}

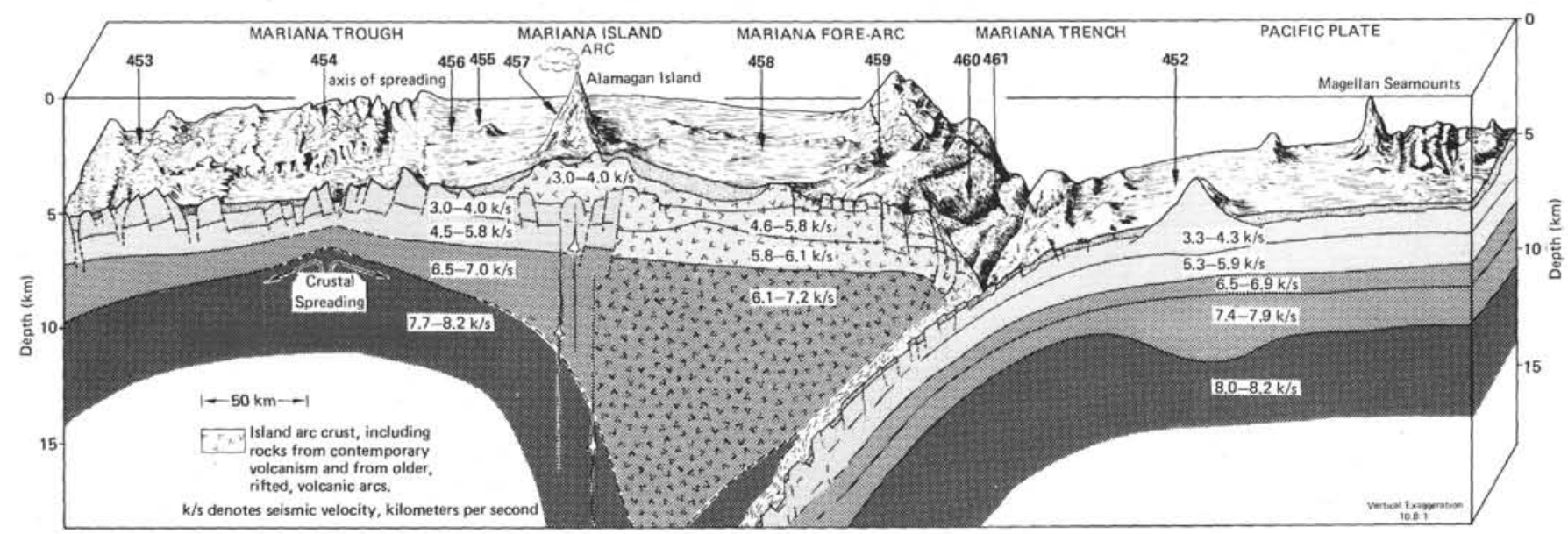

Figure 2. Physiographic diagram and crustal structure across the Mariana Trench and arc and the Mariana Trough, with Leg 60 site location shown. Crustal structure generalized from IPOD site survey data by D. Hussong. Physiography drawn from IPOD site survey data by W. Coulbourn. This diagram summarizes the data and structural interpretations available prior to drilling.

trends, and poorly correlated magnetic anomalies (Bleil, this volume) indicate that the Mariana Trough at $18^{\circ} \mathrm{N}$ is spreading reasonably symmetrically from an axial graben at a half-rate of less than $2.4 \mathrm{~cm} / \mathrm{y}$.

At Sites 454 and 456 , we cored vesicular, sparsely phyric, plagioclase and olivine-plagioclase pillow basalts and thicker flows in short basement sections (Fig. 4). At Site 454 the basalts are fresh and comprise two distinct chemical types and five separate magnetic units, each with average reversed inclinations. The basalts are interbedded with sediments, a feature which showed up clearly on several downhole logs taken at the site. In fact, without the logging we would probably not have identified the intercalated sediments because of low core recovery.

At Site 456 , most of the basalts are hydrothermally altered to chlorite-calcite-quartz-pyrite assemblages, and the lowest tuffaceous sediments are altered to clay minerals-quartz-pyrite-wairakite (identified by X-ray diffraction) assemblages (Natland and Hekinian, this volume). The wairakite suggests that temperatures of al- teration could have been as high as $200^{\circ} \mathrm{C}$ (Liou, 1971) at the peak of hydrothermal activity. Extreme local variability of downhole measured heat flow (2.7 heat flow units at Hole 456, 1.1 heat flow units at Hole 456A) may be a consequence of present-day hydrothermal flux. Extremely variable heat flow in the Mariana Trough, reminiscent of that in the Galapagos area, has been substantiated by a detailed survey made after Leg 60 (Hobart et al., 1979). Despite the hydrothermal alteration, we were able to define four basalt chemical types in Hole 456A (Wood et al., this volume), with two of these types also occurring in Hole 456. Two magnetic units occur in Hole 456 (Fig. 4). Hydrothermal alteration decreases downward in each hole and cuts across chemical units.

The basalts from both Sites 454 and 456 have the chemistry of typical, depleted mid-ocean ridge and interarc basin tholeiites. However, two of the basalts at Site 456 have the trace element characteristics of islandarc basalts, and at Site 454 the depleted basalts have some geochemical components of island-arc basalts. 


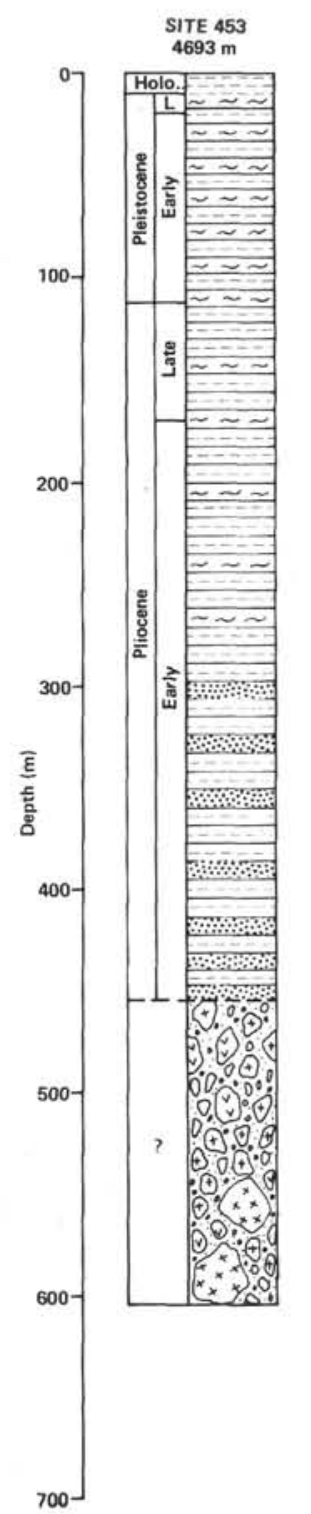

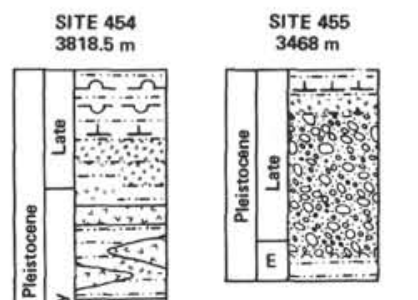
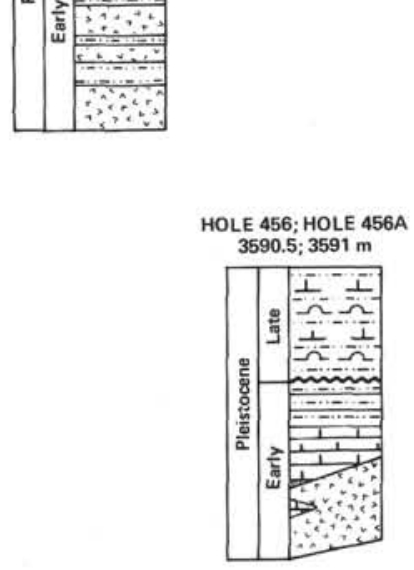
3590.5; $3591 \mathrm{~m}$

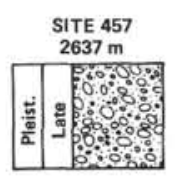

Figure 3. Lithologic columns for sites drilled during Leg 60 .

They were either mixed with arc tholeiite magmas prior to eruption, or partially assimilated arc-derived sediments en route to the surface (Wood et al., this volume). If the former is the case, it could imply simultaneous supply of two fundamental magma types to the center of the Mariana Trough.

At Site 453 , we cored 86 meters of a complex coarse gabbro/metabasalt polymict breccia sequence (several boulders $40-70 \mathrm{~cm}$ in diameter were cored), 62 meters of metavolcanic breccias, and an 18-meter interval from which we recovered 1.5 meters of sheared serpentinized noritic gabbro (Fig. 5). Most of the gabbros and all of the basalts were metamorphosed to greenschist facies assemblages. Metamorphic minerals include prehnite, pumpellyite, epidote, chlorite, quartz, stiphomelane, and biotite. Most of the upper breccia is cemented by calcite and chlorite, with minor quartz and an iron oxyhydroxide staining. A part of the upper breccia, the lower breccia, and the sheared norite gabbro underwent hydrothermal alteration, causing retrograde metamorphism to lower greenschist facies (chlorite-epidotequartz) assemblages, and almost total demagnetization of the affected intervals. Because the pervasive metamorphism and the metamorphic mineral assemblages (especially the biotite) indicate a fairly high pressure of metamorphism, and because there are neither fresh nor altered pillow basalt fragments, we believe that these rocks represent deep-seated parts of the crust uplifted from beneath the West Mariana Ridge, probably during the early rifting of the Mariana Trough. Chemically, the metabasalts and gabbros appear related to rocks drilled at Site 451 on the West Mariana Ridge on Leg 59 (Wood et al., this volume); Natland, gabbros chapter, this volume).

\section{The Mariana Arc, Fore-arc, and Trench Region}

We drilled nine holes at five sites from the active volcanic arc to the trench to investigate (1) the nature and origin of the arc; (2) the effect of the subducting 
east $\longleftarrow$ Hole $456 \mathrm{~A}$

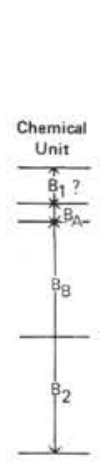

Hole 456
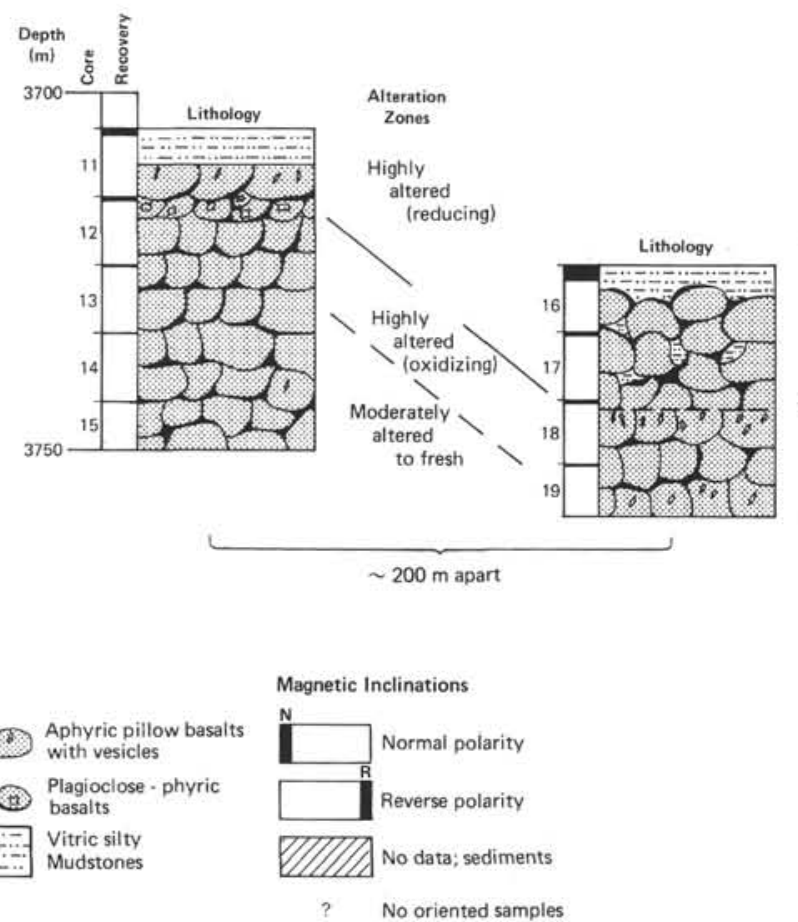

Hole $454 \longrightarrow$ west
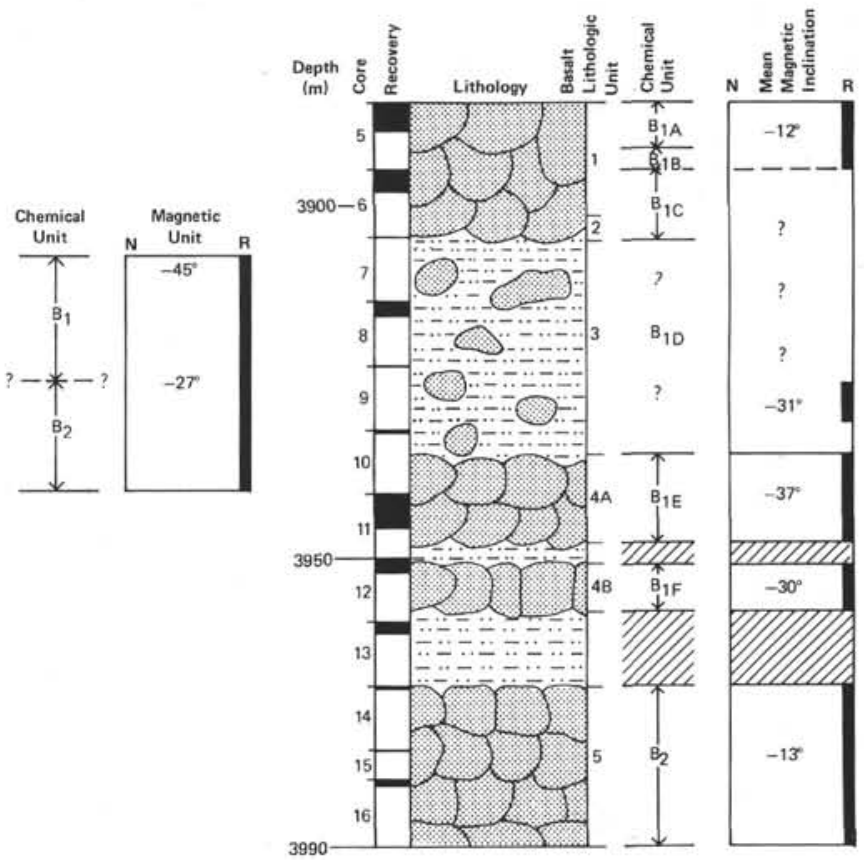

Figure 4. Basement lithologic, chemical, and magnetic stratigraphy, Sites 454 and 456, Mariana Trough.

slab on the arc and fore-arc region (is there an accretionary wedge or prism?); and (3) the volcanic history of the arc and its relationship to the sequence of tectonic events.

At Site 457 (SP-3B), on the volcanic axis of the arc, we failed to penetrate recent coarse pyroclastic sand and ash that mantle the entire region. At Site 458 (SP-3B), on a large fore-arc gravity high associated with a slight bathymetric high, and at Site 459 (SP-3C), just west of the trench slope break, we achieved substantial penetration into igneous basement. Heat flow at both Holes 458 and $459 \mathrm{~B}$ was estimated below one heat flow unit (Uyeda and Horai, this volume). At Site 460 (SP-2B), deep on the inner (island-arc) wall of the trench, relatively shallow penetration revealed Pleistocene oozes overlying Eocene and Oligocene muds, including calcareous sediments. These are presently at depths of more than $6 \mathrm{~km}$. Hole $460 \mathrm{~A}$ revealed redeposited and mixed Quaternary through Eocene sediments. At both holes drilled at Site 461 (SP-2B), deep on the inner trench wall, we recovered reworked sediments and cobbles of igneous and metamorphic rocks having the character of an olistostrome. Sediments from these sites contained some Mesozoic fossils, apparently redeposited from nearby outcrops, including Late Cretaceous radiolarians at both Holes 460A and 461, and Upper Jurassic Calpionellids in Hole 460.

In the Mariana arc-trench gap the sedimentary history begins with deposition of Cenozoic sediments (early Oligocene at Site 458 and Eocene at Site 459) over the island-arc related volcanic basement (Fig. 3). The basal sediments are coarse, highly altered volcaniclastic de- bris. From the Eocene to the middle Miocene the dominant lithologies are nannofossil chalk at Site 458 and thick turbidites at Site 459. Through this same period, calcareous and vitric mud with a pebble layer were deposited at Site 460 , all above the calcite compensation depth. The sequences in these holes have several hiatuses, the most prominent of which was from the late Miocene to the Pliocene at both Sites 458 and 459 . There was an increase in biogenic sedimentation in the Pleistocene, with siliceous oozes as the most recent sediments at Sites 458, 459, 460, and 461 .

The arc-trench sites are a good example of tectonically controlled sedimentation. At Site 458, the Oligocene-Miocene chalks seem to have been deposited near the Equator (the apparent northward movement of the older Mariana arc system is also supported by changes in paleomagnetic inclinations measured on board). The absence of turbidites in any of the Site 458 cores suggests that uplift characterized this part of the fore-arc, or that deposition occurred on a bathymetric high. In contrast, at Site 459 , thick turbidites were deposited during early Oligocene and early Miocene times, indicating subsidence relative to the surrounding region.

Sediment reworking and redeposition are a constant feature of all the sites, even during the quiet (chalk, etc.) sequence at Site 458.

The upper part of the basement rocks at Site 458 comprise bronzite and clinopyroxene-bearing, nearly plagioclase-free lavas which chemically resemble highmagnesian andesites found associated with boninites, an unusual and rare rock-type found in some island arcs (Fig. 6). Characteristics of the rocks from Site 458 


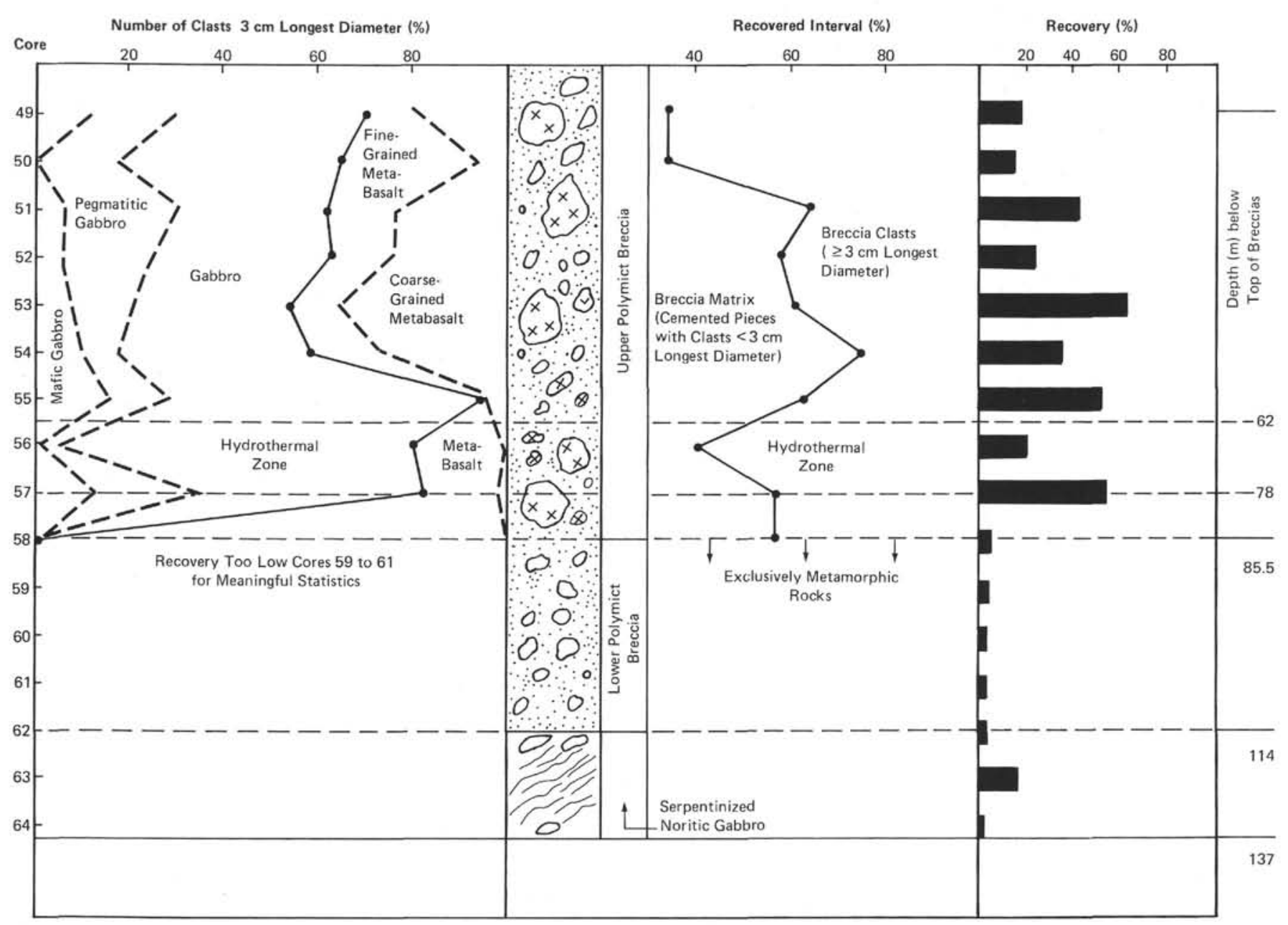

Figure 5. Stratigraphy of the gabbro-metabasalt polymict breccia sequence cored at Site 453 .

(Wood et al., this volume) are high $\mathrm{Ni}(60-100 \mathrm{ppm}), \mathrm{Cr}$ (170-300 ppm), and $\mathrm{MgO}(6.1-9.2 \%)$, but very low $\mathrm{TiO}_{2}(0.28-0.51 \%)$ and $\mathrm{Zr}(29-51 \mathrm{ppm})$, even though $\mathrm{SiO}_{2}$ is high (52-54\%). These are interbedded with twopyroxene basalts which chemically resemble tholeiitic basalts found at Site 459 and in many island arcs. At Site 458 , we recognize two chemically similar high-magnesian andesite types (Chemical types $A_{1}$ and $A_{2}$ on Fig. 6 ) and two basaltic types (Chemical types $B_{1}$ and $B_{2}$ ). We found nine separate magnetic units with distinct inclinations in the hole. The upper five (all positive) all occur within the upper high-magnesian andesite; the lower four (all reversed) span the basalt types and the lower andesite. Some magnetic unit boundaries correspond with chemical unit boundaries, and hence may represent secular variations in the Earth's magnetic field. One reversal occurred between eruptions. Other magnetic unit boundaries occur within chemical units and correlate with zones of intensely fractured rocks; hence they appear to have been produced by faulting.

Basement rocks in Hole 459B (Fig. 6) are vesicular clinopyroxene-plagioclase pillow basalts, flows, and possibly sills. Thicker units contain quartz-alkali feldspar micrographic intergrowths, indicating that the basalts are tholeiitic, and experienced some post-eruptive fractionation. Chemically (Wood et al., this volume), the rocks are high in $\mathrm{SiO}_{2}(51.1-58.6 \%)$, quartz-normative, and contain low $\mathrm{TiO}_{2}(0.7-1.2 \%)$, $\mathrm{Ni}(11-57$ ppm), and $\mathrm{Zr}$ (36-73 ppm). Iron as $\mathrm{Fe}_{2} \mathrm{O}_{3}(9.8-13.6 \%)$ covers a broad range, indicating that most of the basalts are highly fractionated and show the typical iron enrichment of many island arc tholeiite suites. Iron enrichment among Site 459 basalts is greater than among Site 458 basalts, and probably accounts for extremely high intensities of magnetization in Cores 65 and 71-73, where iron enrichment is greatest. In all, seven chemical units were recovered in Hole 459B. Magnetic inclinations were shallow and of both normal and reversed polarity (Fig. 6). At both Sites 458 and 459, many of the basalts are intensely fractured and highly altered to smectite-phillipsite assemblages. At Site 459, there was an early oxidative stage of possible hydrothermal alteration in which palygorskite and celadonite formed in fractures in the basalts (Natland and Mahoney, this volume). This is the first reported occurrence of secondary palygorskite in basalts although it is a fairly common authigenic mineral in marine sediments.

At Sites 460 and 461 , we cored polymict assemblages of basalts, metabasalts, bronzite andesites, and gabbros reminiscent in certain respects of the breccias at Site 
Site 458

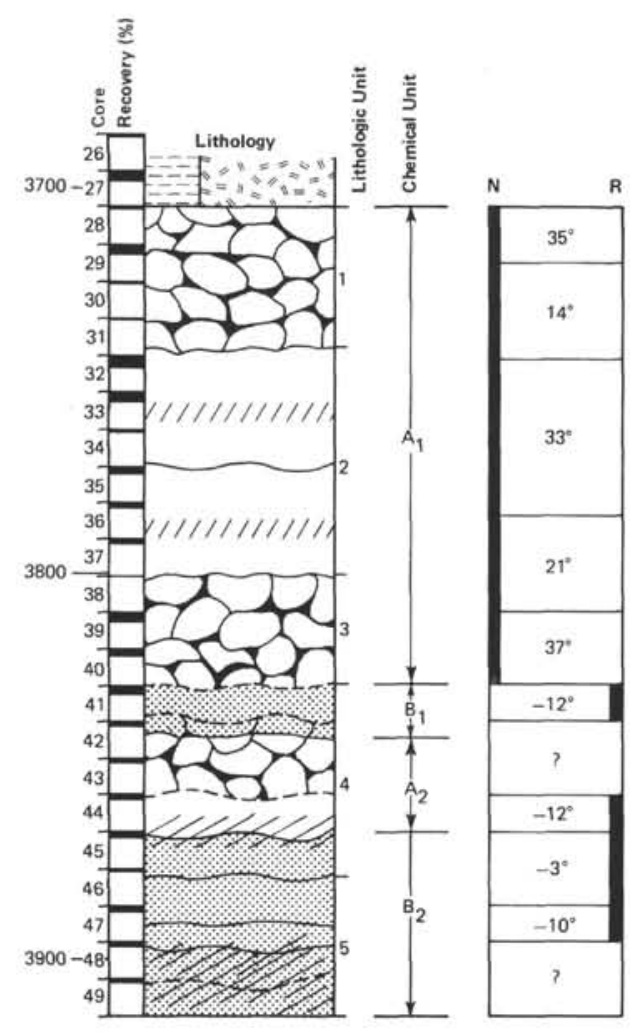

Hole 459B

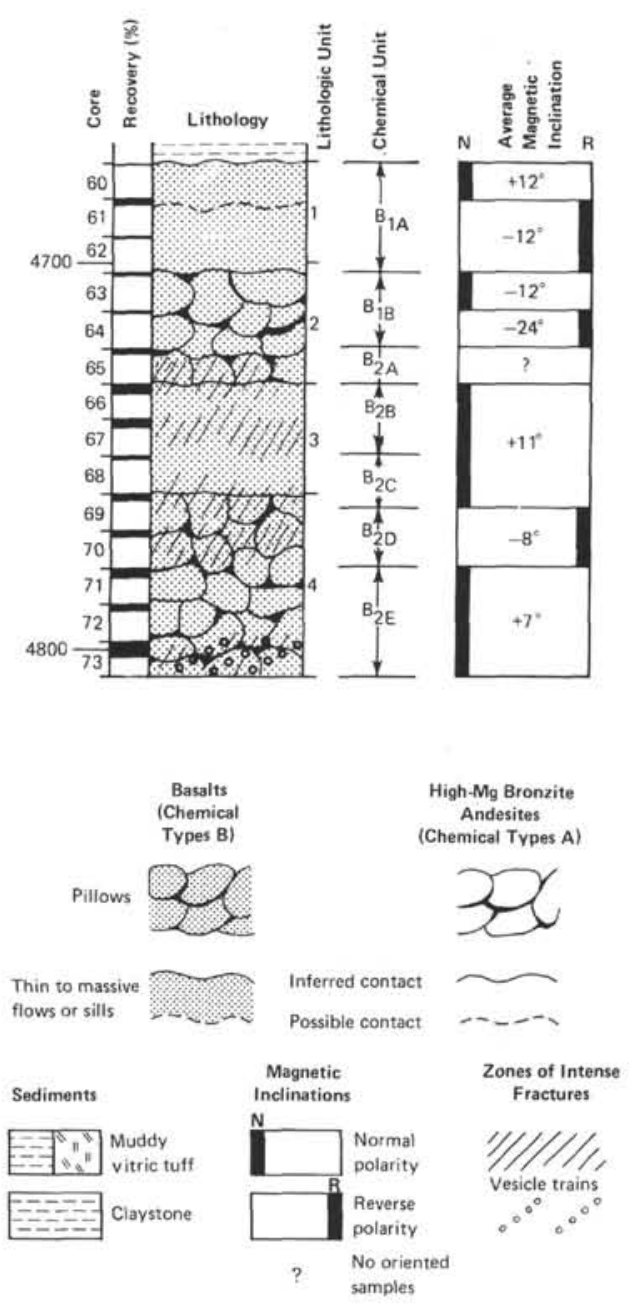

Figure 6. Basement lithologic, chemical, and magnetic stratigraphy, Sites 458 and 459 in the Mariana forearc region.

453 , except that amphibole is the only major hydrous mineral in the metabasalts and gabbros. Biotite and stilpnomelane are absent. This indicates a lower-pressure, possibly higher-temperature grade of metamorphism, one perhaps more typical of oceanic crust. Chemically, however, the few analyses we have (Wood et al., this volume) indicate that the rocks have island-arc, rather than ocean crust, affinities (i.e., they have lower $\mathrm{TiO}_{2}, \mathrm{Ni}$, and $\mathrm{Zr}$, at generally higher $\mathrm{SiO}_{2}$ contents, than igneous rocks of the ocean floor). This indicates that they are probably fragments of deeper ancient arc basement.

The principal petrologic conclusions we derive from all these sites are that igneous basement in the fore-arc trench region is primarily arc-related, extends to very nearly the trench-slope break, and probably crops out in the upper trench wall. We do not know how far downslope the igneous and metamorphic cobbles at Sites 460 and 461 may have slumped, nor do we know if they overlie a larger, structurally coherent igneous or meta- morphic sequence of autochthonous (arc-related) or allochthonous (ocean crust) origin. We do not know the source of the reworked Cretaceous radiolarians nor the Calpionellids at Sites 460 and 461.

The following conclusions combine the major sedimentological and structural/tectonic inferences we draw from the fore-arc drilling augmented with seismic data. The age of the oldest sediments in each hole increases toward the trench, and vertical movement and tensional features dominate the fore-arc and trench regions. These tensional features range from the scale of blockfaults and slumps observed on seismic reflection records, to small-scale penecontemporaneous normal faults seen in cored sediment samples. The intense fracturing of basement rocks at Sites 458 and 459 is also probably related to the the tectonic disturbance seen in the sediment cores. The principal vertical movement has been downward with the amount of subsidence increasing toward the trench, as indicated by the location of calcareous sediments related to the calcite compensation 
depth, the presence of turbidites, and the degree of reworking.

The suggestion that pieces of Pacific Ocean floor should fault into the western side of the trench, enlarging and uplifting the fore-arc region, now faces contrary evidence. Although some rocks found in the deepest holes in the trench wall may originally have been part of an old oceanic or back arc basin crust, it now appears that subduction in the Mariana Trench is a smooth process that involves little, or no, accretion of material from the Pacific plate.

\section{SUMMARY OF OPERATIONS}

Leg 60 began on 15 March, 1978 at Apra, Guam and ended at the same location on 15 May, 1978. A brief port call was made a Janapal Harbor on the island of Saipan to disembark an injured crewman plus a scientist, and also to take on supplies, particularly drilling equipment needed to complete the objectives of the leg.

During Leg 60, the Glomar Challenger traveled 2445 nautical miles and attempted to drill 17 holes at 10 sites. These holes ranged from a very short 3.5 meters in Hole 459 , when the inner core barrel unscrewed and the string had to be pulled, to 691.5 meters at the same site in Hole 459B. Water depths ranged from 2647.0 meters to the record-setting 7044 meters at Hole $461 \mathrm{~A}$. A total of 2706.0 meters of coring was attempted, with 833.01 meters $(30.8 \%)$ being recovered (Table 2 ).

In all reports on operations depths are below the rig floor. In all other sections of this volume depths are below sea level.

Time distribution for the leg (Fig. 7A) was 7.11 days in port, 12.08 days cruising, and 41.96 days on site. The on-site time consisted of 11.13 days tripping, 0.09 days

Table 2. Operational resume, Leg 60 .

\begin{tabular}{|c|c|c|}
\hline \multicolumn{2}{|l|}{ Total days (March 15, 1978-May 15, 1978) } & 61.15 \\
\hline \multicolumn{2}{|l|}{ Total days in port } & 7.11 \\
\hline \multicolumn{2}{|l|}{ Total days cruising including site survey } & 12.08 \\
\hline \multicolumn{2}{|l|}{ Total days on site } & 41.96 \\
\hline Trip time & 11.13 & \\
\hline Drilling time & 0.09 & \\
\hline Coring time & 22.08 & \\
\hline Waiting on weather & 0.67 & \\
\hline Position ship & 1.52 & \\
\hline Mechanical repair & 0.08 & \\
\hline Other (include logging) & 6.39 & \\
\hline \multicolumn{3}{|l|}{ Total distance traveled } \\
\hline (nautical miles) including survey & & 2445 \\
\hline Average speed (knots) & & 8.76 \\
\hline Number of sites & & 10 \\
\hline Number of holes drilled & & 17 \\
\hline Number of cores attempted & & 293 \\
\hline Number of cores with recovery & & 280 \\
\hline Cores with recovery $(\%)$ & & 95.5 \\
\hline Total meters cored & & 2706.0 \\
\hline Total meters recovered & & 833.01 \\
\hline Recovery $(\%)$ & & 30.8 \\
\hline Total meters drilled & & 115.0 \\
\hline Total meters of penetration & & 2831.0 \\
\hline Penetration cored $(\%)$ & & 95.9 \\
\hline Maximum penetration (m) & & 691.5 \\
\hline Minimum penetration (m) & & 3.5 \\
\hline Maximum water depth ( $\mathrm{m}$ below rig $\mathrm{fl}$ & or) & 7044.0 \\
\hline Minimum water depth ( $\mathrm{m}$ below rig $\mathrm{fl}$ & & 2647.0 \\
\hline
\end{tabular}
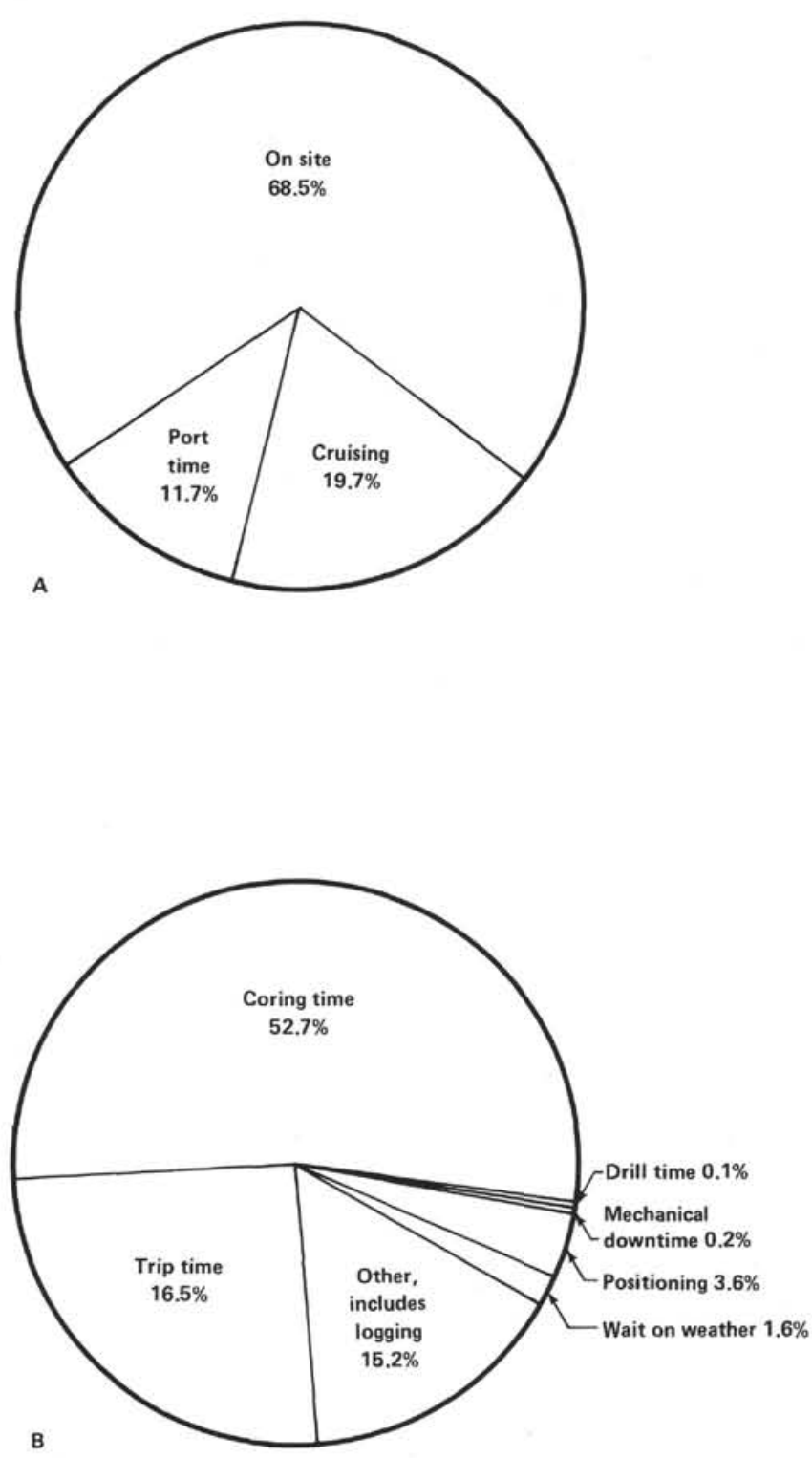

Figure 7. (A) Total and (B) on-site time breakdown for operations during Leg 60.

drilling, 22.08 days coring, 0.67 days waiting on weather, 1.52 days positioning the ship, 0.08 days of mechanical downtime, and 6.39 days for miscellaneous work, such as running the downhole logging equipment and the Institute of Oceanographic Sciences resistivity experiment (Fig. 7B).

Most of the scientific objectives of the leg were achieved, and a major technical accomplishment was the successful recovery of cored materials while operating in a water depth of 7044 meters. The leg was also successful in recovering cored material employing the longest drill string used to date and in successfully operating in the deepest water ever attempted by the Challenger.

\section{DRILLING AND CORING ASSEMBLIES}

Five bottom-hole assemblies were used on this leg. The more or less standard assembly was used on Holes 
$452,452 \mathrm{~A}, 453$, and 455 . This consisted of the bit, bit release sub, top connector, one 8.25 -in. drill collar, top conversion sub, head sub, three 8.25 -in. drill collars, one 5 -ft bumper sub, three 8.25 -in. drill collars, two 5 -ft. bumper subs, two 8.25 -in. drill collars, crossover sub, one 7.25-in. drill collar, and one joint of 5.25-in. drill pipe. A variation of this was necessary after losing two top connectors for the bit disconnect set-up. At Holes 457, 458, 461, and 461A, no bit disconnect set-up was used and a regular bit sub was used in its place. On Holes 457, 458, 459, 459A, 459B, 460, 460A, and 461A, another change was made in the top stand of collars. The last remaining 7.25-in. drill collar was lost at Site 456 , when it became necessary to shoot off the bottomhole assembly. An 8.25-in. drill collar was then substituted for the 7.25-in. drill collar in the holes remaining.

Still another assembly was used on Holes 454, 454A, 456 , and $456 \mathrm{~A}$. It consisted of a bit, bit disconnect sub, top connector, core barrel, top sub, head sub, three 8.25 -in. drill collars, one 5 -ft bumper sub, two 8.25 -in. drill collars, crossover sub, one 7.25-in. drill collar, and one 5.5-in. R-3 joint of drill pipe.

The bit release sub was run to provide an opportunity for downhole logging.

\section{BITS}

Two F94CK bits were used on the first three holes drilled. The first of these was lost when part of the bottom-hole assembly was found broken off after 28 meters of penetration in Hole 452. The second was released in Hole 453 after the bit had apparently worn out, so that the hole could then be logged.

The remaining 14 holes were drilled using F93CK bits. This change was made to ensure that there would be enough F984CK bits on board to drill a planned major re-entry on Leg 61. A hoped-for shipment of new bits and could not be expedited for Leg 61 . The two bits recovered were in good shape after 23.5 and 8.18 hours, respectively.

\section{BEACONS AND POSITIONING}

Ten beacons were used on this leg: three $16.0-\mathrm{kHz}$, double-life units; two $16.0-\mathrm{kHz}$, single-life units; four $13.5-\mathrm{kHz}$, double-life units; and one $13.5-\mathrm{kHz}$, singlelife unit. All performed well. Dynamic positioning was very good. On the last three holes (Holes 460, 461, and $461 \mathrm{~A}$ ) - where the water depths were 6454,7039 , and 7044 meters, respectively-the gains were increased. This was required to maintain a signal level that was acceptable and was accomplished with no trouble. Weather created no positioning problems on this leg.

\section{ELECTRIC WIRELINE LOGGING}

Downhole logging was conducted again on this leg with tools and operations personnel supplied by Gearhart-Owen Wireline Service. Logging was successful in Holes 454A and 459B, but not in Hole 453, where the tools could not pass through a section of bent pipe.

The drill string was assembled with a bit release setup on all sites, with the exceptions of Sites 457,458 , and 461 . When both of the bit releases had been lost, an ad- ditional unit was picked up in the short call in Saipan; the logging capability was then restored. The disconnect assembly was not run at Site 461 because of the deep water $(7000 \mathrm{~m})$ and the uncertainty of the amount of sediment that had been deposited. All the GearhartOwen equipment worked well with the exception of one sonic log.

\section{SITE-BY-SITE OPERATIONS SUMMARY}

\section{Site 452-Northern Mariana Basin}

The first site to be investigated on Leg 60 was located approximately 350 miles northeast of Guam. A 13.5$\mathrm{kHz}$, double-life beacon was dropped at 1358 on 23 March at the proposed location, and at 1546 the ship was positioning itself in the automatic mode with a 1000 -ft. southerly offset from the beacon. This offset was used to obtain the best geologic results as interpreted from the geophysical data available. The running of the drill string was then commenced.

The PDR (Precision Depth Recorder) indicated a bottom depth of 5868 meters. However, while running in, the seafloor was encountered at 5838 meters. The Bowen sub was picked up and a mudline core was cut. When the overshot was lowered, the core barrel could not be retrieved and the shear pin was sheared. This was replaced on the next trip, and the core barrel was recovered but required a pull of about 13,000 pounds.

The next core barrel was dropped and it appeared to seat properly with only a slight variation in what the proper pressure should have been. Core 2 was recovered after some difficulty, but no pins were sheared. Core 3 also showed only a slight variation in the expected pressure build-up when the barrel landed. However, the core barrel could not be recovered after cutting the core. After two pins were sheared, we decided to pull the drill string.

When the string was recovered, the bit, bit release sub, top connector, outer core barrel, and two 8.25 -in. drill collars were missing. The inner core barrel was protruding from the next drill collar, where it was wedged in the bent pin of the collar. Apparently this was the same place the core barrel had landed and Cores 1 and 2 were taken.

This loss was apparently due to error in pipe measurement and when the pipe ran into bottom, it broke off. With careful measurements on the next hole, the location of bottom agreed with the PDR readings.

A new bottom-hole assembly was made up and the drill string run again in Hole 452A. This time the pipe was measured before it was run and a mudline core indicated bottom to be at 5872.5 meters, confirming the PDR measurement. Continuous coring then began, but after four cores had been cut to a depth of 37 meters chert was encountered. Core 5 required 30 minutes to cut and when the barrel was dropped to Core 6, 50 minutes of rotating time was required to reach the total depth of Core 5. Torquing had increased greatly and as only about one-third of the bottom-hole assembly was buried, it was necessary to abandon the hole to protect the drill string and the one remaining top connector for 
the bit-release system. The latter piece of equipment was essential to the planned logging program scheduled for Leg 60 and had to be preserved if possible. The drill string was pulled and the site abandoned at 0415 on 27 March.

\section{Site 453-Western Mariana Trough}

After abandoning Hole 452A, the ship steamed west approximately 225 miles before dropping a $16.0-\mathrm{kHz}$, double-life beacon at 1318 on 27 March for Site 453.

The drill string was made up and run to bottom. The mudline core established bottom at 4703 meters, which was the same depth as recorded by the PDR. The hole was continuously cored to a total penetration depth of 605.0 meters sub-bottom. Relatively soft rocks consisting of ashes and ashy mudstone were cored to about 455 meters, where hard, dense gabbro and breccia were encountered. This continued to total depth. After reaching total depth, 150 barrels of mud was circulated to clean the cuttings out of the hole. A shifting tool was then run and the bit released, which made it possible to carry out a logging program.

While the pipe was being pulled uphole, some torquing and sticking developed. A circulating head was installed and the pipe was washed down three joints. While this was being done, the bit took about 35,000 pounds of weight.

When the first log reached a depth of 4677.6 meters, it stopped and required about 600 pounds of overpull to move it. The tool was then lowered carefully, but again it stopped at $\mathbf{4 6 7 7 . 5}$ meters. We concluded that the drill pipe must be bent, so the tool was pulled. The drill string was also recovered. When it was first picked up, the hanging weight was 325,000 pounds or about 50,000 pounds lighter than it should have been, but the weight increased to 450,000 pounds before it could be moved and reverted to its normal weight of 375,000 pounds. When the third joint above the bottom-hole assembly was pulled to the derrick floor, we found it was bent and this had caused the logging tool to stop. The balance of the string was in good condition, but the site was abandoned at 0942 on 4 April.

\section{Site 454-Central Mariana Trough}

This site was located approximately 50 miles east of Site 453. After steaming about 10 hours, a $16-\mathrm{kHz}$, double-life beacon was dropped at 1940 on 4 April.

The drill string was made up, and Hole 454 was spudded at 0720 on 5 April. The mudline was found to be at 3828.5 meters, and then three more cores were cut and recovered. A heat flow experiment was conducted and followed by one more core. At this point, owing to rapidly changing sea conditions, we decided to stop drilling, pull out of the hole, and wait for the weather to improve. Thus Hole 454 was abandoned at 1636, 4 April, when the pipe was pulled above the mudline.

Excessive rolling of the ship, up to $13^{\circ}$, while tripping out the drill pipe from Hole 454, required that only one stand per hour be pulled. This procedure to protect the drill string was necessary for a 16-hour period before routine tripping could be resumed.
Hole 454A was spudded at 1218 on 6 April. After the first core, three joints of pipe were washed in and then the hole was continuously cored to total depth. Igneous rock was encountered after approximately 63 meters of sediments had been penetrated. This condition had been anticipated from the seismic records, and a short bottom-hole assembly $(82.99 \mathrm{~m})$ had been used instead of the normal 120-meter assembly.

After cutting Core 14, and before starting to retrieve the core, the drill string stuck and could not be rotated. The heave compensator was closed and locked. The pipe was worked for about 10 minutes, when it came free and would rotate. After retrieving the core, a 30-barrel mud fill was spotted and this seemed to aid in working the drill string back to bottom. Core 15 required 48 minutes to cut, and some torquing developed. After Core 16, 42 minutes were spent working with the torquing and sticking drill pipe before it was free enough to run in after the core. Before starting to cut Core 17, 30 barrels of mud were again spotted, but 9 meters of fill was found when starting back to bottom. It took 50 minutes to clean back to bottom; when the pipe reached there, it became stuck and required pulls as high as 540,000 pounds to free it. At this point, we had to abandon further attempts to drill deeper, and an attempt was made to $\log$ as much of the hole as possible.

Pipe was pulled to 3968.5 meters, which was above the unstable portion of the hole, and a heat flow test was conducted. After this experiment, the shifting tool was rigged and the bit released; the pipe then was pulled to 3911.5 meters for the logging program.

After the logging sheaves were rigged, the following logs were run through the interval 3911.5 to 3977.0 meters; induction-gamma ray, compensated density log, deep Laterolog, B.H.C. sonic log, and differential temperature log. This required about 24 hours to complete. A resistivity experiment was then conducted which took about nine more hours. Subsequently, the drill string was pulled and the site was abandoned at 2310 on 9 April.

\section{Site 455-Eastern Mariana Trough}

After steaming in an easterly direction for about 12 hours, a $13.5-\mathrm{kHz}$, double-life beacon was dropped at 1230 on 10 April and work began. The drill string was made up and run to bottom, where a mudline was estab-

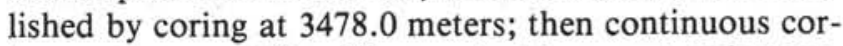
ing was begun. After 10 cores had been cut and recovered and while waiting for the heat flow tool to be assembled, the pipe became stuck. In attempting to work free, we learned that the heat flow equipment was not operating properly and the test would be deferred. The drill pipe was finally worked free after pulling more than 50,000 pounds over hanging weight several times. The apparent reason for the sticking was the loose volcanic sand material which was topped in Core 3 and continued to be recovered as the hole was drilled deeper. While cutting Core 11 , the torquing and sticking continued; as it was too hazardous to work with, the hole was abandoned at 1930 on 11 April. 


\section{Site 456-Eastern Mariana Trough}

Following the early abandonment of Site 455 , the ship traveled about 11 miles westerly and dropped a 16.0-kHz, single-life beacon on 12 April.

The bit was made up and run, and a bottom depth of 3600.5 meters was established with a mudline core in Hole 456. Three cores were cut and recovered, and a combination heat flow and pore water sampler was run. The hole was then continuously cored to a sub-bottom depth of 161.5 meters, where the pipe began torquing. A 30-barrel slug of mud was then spotted before running back to cut the next core. When subsequently the pipe was run back, bottom was found to be 4.5 meters high. The pipe was worked through this fill but during the coring from 161.5 to 169.0 meters torquing and sticking again returned, requiring a pull of over 400,000 pounds to loosen the string. The pipe was pulled to 159 meters sub-bottom and another 30 barrels of mud circulated. When starting back, the pipe started taking weight just below 159 meters; after 45 minutes of rotating it was only 166 meters deep and had been torquing and sticking all through this operation. Because of this hazardous condition, it was necessary to abandon the hole and offset the ship from the beacon, in hope of finding a better location. The drill string was pulled above the mudline at 2115 on 13 April and the hole was officially abandoned.

After clearing the mudline at Hole 456, the ship was offset 700 feet easterly, and Hole 456A was spudded and established a seafloor depth of 3601.0 meters with a mudline core on 14 April.

Following the mudline core, two singles were washed in and then two cores were recovered. A heat flow measurement was taken, followed by two more cores, and then heat flow measurement No. 2 was taken at 66.5 meters sub-bottom. The hole was subsequently cored to a depth of 133 meters. After Core 12 had been recovered the pipe showed indications of fill; so it was decided not to run a third heat flow measurement, and 30 barrels of mud was spotted before continuing to core. After the mud had been circulated fill was encountered five meters above the depth reached in Core 12 , and 15 minutes was required to work back to bottom. Core 13 was cut and recovered with no additional problems. However, while coring Core 14, the pipe became stuck and required a pull of 410,000 pounds to free it. After Core 14 was cut (69 min rotating time) and recovered, the bit tagged bottom six meters high. After taking 15 minutes to clean to bottom, coring began but torquing and sticking were encountered immediately. After coring seven meters in 72 minutes with repeated stopping and starting, we decided to discontinue coring, pull up to a free point, drop the bit and $\log$ the hole. The bit was pulled up to what appeared to be a safe spot above the fill, and the core barrel was retrieved. The shifting tool was lowered and the bit released at $\mathbf{3 7 4 0 . 5}$ meters.

The shifting tool was recovered and when the drill string was picked up, it was found to be stuck. Sixty barrels of mud was spotted, and attempts began to free the pipe. Two hours were spent but no progress was made, so a 20-barrel batch of guar gum was mixed and pumped down but to no avail. During all this time the bumper sub was not working (there was only one in the short $83 \mathrm{~m}$ of bottom-hole assembly). After working over five hours with pulls as high as 580,000 pounds, it was necessary to shoot the pipe off.

A shot was made up and run to 3643 meters (identified by tool joint at $3638 \mathrm{~m}$ ) and firing was attempted; however, nothing happened. When the charge was recovered, it showed that the cap had fired but the prima cord had not ignited. A second attempt had the same results. We felt that possibly a leak was developing in the cap prima cord connection; so on the third attempt, this was taped and scotch-coated. On this attempt, when the charge exploded, the 5 -in. drill pipe in the first joint above the 5.5 -in. heavy wall was severed. The drill string was recovered with no other problems, and the site was abandoned at 0030 on 16 April.

\section{Site 457-Mariana Arc}

This site was located 37 miles east of Site 456 , but 12 hours was spent profiling before a decision as to its final location was made. There was concern among the scientific staff whether the type of rock that would be encountered here would be drillable. A $13.5-\mathrm{kHz}$ doublelife beacon was dropped at 1400 on 16 April and the drill string was made up. The PDR indicated a water depth of 2640 meters, but a core taken to a depth of 2641.5 meters recovered only water. A single section of drill pipe was added and encountered resistance of 2647.0 meters and required 11 minutes of rotation to cut four meters. However, when the core barrel was recovered it was empty. Core 2 recovered about four meters of loose, coarse black volcanic sand, as did Cores 3 through 7. However, while cutting Core 7, the pipe began torquing and sticking, requiring as much as 360,000 pounds pull to free it. Because of the thick section of sand already penetrated, and not knowing its total thickness, combined with the increased hazard to the drill string, we decided to leave this location. The drill string was then pulled and the site abandoned at 1530 on 17 April.

\section{Site 458-Mariana Fore-arc Region}

Although this site was located only 64 miles east of Site 457 , about 10 hours was spent profiling to locate an area with enough sediment to spud-in safely as far as the equipment was concerned. A $13.5-\mathrm{kHz}$, double-life beacon was dropped at 0148 on 18 April and work commenced.

The drill string was made up and the site was spudded at 0921 on 18 April. Two hundred and sixty-six meters of sediment was cored before igneous rock was encountered. While this section was being cored, two heat flow measurements were taken at 76.0 and 142.5 meters sub-bottom.

After recovery of Core 38 , the bit became plugged but was cleared after working on it for about 20 minutes. Before starting to cut Core 39,40 barrels of mud were circulated to help cure the bit plugging condition. Mud was spotted again before cutting Core 48 . 
However, the drill pipe became stuck after Core 49 had been recovered in spite of mud flush. At first the pipe could not be rotated or circulated, and pulls up to 425,000 pounds would not move it. After working about one half hour, the pipe was moved without an overpull, but circulation could not be regained. We decided then to pull the pipe to a logging depth (bottomhole assembly below the mudline), recover the core barrel, and see if circulation could be regained. The first attempt to retrieve the inner barrel was unsuccessful; however, on the next try the inner barrel was recovered and circulation was again achieved.

An effort was made to run logs through the bit by dropping a modified inner barrel to hold the float valve open. After the pipe was positioned with the bit at 3579.5 meters, the temperature log was run. When the tool reached 3566 meters or the top of the inner barrel, it stopped. After repeated attempts to get past this point met with no success, the tool was pulled. The gammaneutron log was made up and encountered the same difficulty. It too was pulled. We then decided that logging was not possible, so the entire drill string was pulled. The site was officially abandoned at 0900 hours, 22 April.

\section{Port Call at Saipan}

After completing Site 458 , the next site was located 21 miles due east. However, this move was delayed because it was necessary to go to Saipan to pick up needed parts and to disembark one crew member and a scientist. A vessel that had been chartered to bring the parts to the Challenger, and which could have been used to transfer the personnel, developed engine problems and could not arrive soon enough to allow continuation of the logging program at Site 458 . It was not possible to estimate the repair time for the engine problems; so it became evident that the best course was for the Challenger to steam to Saipan.

\section{Site 459-Mariana Fore-arc Region}

The ship returned from Saipan, and at 0604 on 25 April a $13.5-\mathrm{kHz}$, single-life beacon was dropped for Site 459. The drill string was made up and run and a mudline core taken. Just as this core was being pulled from the pipe at the derrick floor, the barrel came unscrewed and dropped the bottom part of the core barrel and the core liner back to the bottom of the drill string. Two attempts were made to fish these parts out, but both failed. It was thus necessary to pull the drill string so coring could continue. The bit was on the derrick floor at 0030 on 26 April and Hole 459 ended.

Make-up of the bottom-hole assembly was begun as soon as the inner core barrel parts were recovered and the drill string was rerun. As this site was a potential reentry location, Hole 459A was used to determine how much casing could be attached and washed in with a reentry cone. The hole was spudded at 0726 on 26 April and required 73 minutes to wash the pipe to a sub-bottom depth of 67 meters. This was considered the casing depth, because the sediments had firmed up sufficiently near the bottom of the hole. The pipe was then pulled clear of the mudline at 0933 and was ready to drill Hole 459B.

After offsetting the ship 50 feet east, another mudline core was taken when Hole 459B was spudded at 1100 on 26 April which established bottom at 4125.5 meters. During the coring operation, four heat flow measurements were taken at $64.5,121.0,197.5$, and 330.5 meters.

After Core 72 had been cut and before it could be retrieved, the drill string began sticking. The overshot was recovered and work began on trying to free the pipe. After about an hour the pipe was free enough to allow the recovery of the core barrel. After the core barrel had been recovered the pipe again began torquing, so it was decided to discontinue drilling and log the hole before conditions became worse.

The string was pulled to a free point above the sticking area $(5788.5 \mathrm{~m})$, and the shifting tool was run and the bit dropped at 0753 on 2 May. The drill string was then pulled to 4244.0 meters, and preparations for logging were started. Initially, five log runs were made involving the following tools: gamma-density, gammasonic/caliper, gamma-neutron guard (Laterolog), gamma induction, and temperature. A resistivity experiment was conducted while the gamma-sonic tool was repaired. A moderately successful gamma-sonic log was later obtained.

After the logging program had been completed (approximately $39 \mathrm{hrs}$ ), the string was pulled and the site was abandoned at 0930 on 4 May.

\section{Site 460-Mariana Trench}

This site was located only 21 miles southeast of Site 459; however, 10 hours was spent profiling before a $16.0-\mathrm{kHz}$ beacon was dropped at 1935 on 4 May. The sediment pond of the site was rather small and located in deep water ( 6400 plus) on the west side of the Mariana Trench.

The drill string was made up and run, making certain that the upper section of the drill string consisted of new pipe. On 5 May, Hole 460 was spudded in the deepest water ever drilled by the Challenger. The mudline was established at 6461.5 meters with a mudline core. Coring then continued with penetration rates very slow for the type of material recovered. Core 6 recovered 1.9 meters of what appeared to be mainly cuttings ranging from coarse-grained, one-half inch fragments to finegrained. Therefore, before Core 7 was cut, the hole was circulated with 20 barrels of mud in the hope that this material could be cleaned out. Recovery was poor for Cores 7,8 , and 9 , and each took more than 40 minutes to cut. When starting Core 10, about six meters of fill was encountered and required 24 minutes to clean out. After cleaning to bottom, the pipe was rotated for 109 minutes with no apparent penetration. We decided to stop drilling, pull above the mudline, and move the ship to a more favorable location. After pulling the pipe above the mudline, the overshot was lowered to recover the core barrel; however, no contact was made at the depth that the inner barrel should have been. When the 
overshot was recovered and the pump turned on, the pressure indicated that the inner barrel was gone.

The drill string was pulled and when it was recovered, the bit release sub and bit were missing. The tool had shifted in some unknown manner and the bit had been released. On examination of the top connector, we noted that the sleeve retainer had been worn down about one-half inch. This indicated that the pipe had been rotated quite a while after the release had taken place. The bottom-hole assembly came to the derrick floor at 2400 on 6 May and Hole 460 was ended.

After the drill string was recovered from Hole 460, new offsets of 950 feet south and 400 feet west of the beacon were put into the positioning program. A new bit-release assembly was attached to the bottom-hole assembly, and the drill string was run to bottom. Hole $460 \mathrm{~A}$ was spudded at 1549 on 7 May.

The core recovery was very much like that encountered in Hole 460. The drill rate continued to be slow and recovery was poor, averaging about 30 per cent. After Core 10, 30 barrels of mud was pumped into the hole to clean out the fill. After 93 minutes, only six meters had been cut on Core 11 when suddenly the drill string would not rotate. Pulls up to 525,000 pounds were made before the string could be rotated and pulled above the tight spot. Because of the poor recovery, deep water, and poor hole conditions, we decided to stop drilling. The pipe was pulled and Hole $460 \mathrm{~A}$ was abandoned at 1300 on 9 May.

\section{Site 461-Mariana Trench}

The proposed location of this site was about eight miles northeast of Site 460 . However, it required eight hours of profiling until a satisfactory location was chosen. A $16.0-\mathrm{kHz}$, single-life beacon was dropped at 2100 on 9 May and Site 461 began.

The PDR indicated a record water depth for the Challenger of 7044 meters. When the drill string was made up and run, a mudline core showed a water depth of 7039 meters. The first core in Hole 461 was only 1.5 meters long and required 18 minutes of drilling. The next core was 9.5 meters and also required 18 minutes of rotation and some pump. The third core, which bottomed at 20.5 meters, needed 65 minutes to cut. With the drilling time so long plus the extremely deep water, we decided to abandon this location and to make an attempt to find a more suitable location in the near vicinity. We hoped that a thicker, easily drilled sediment section could be found which would protect the drilling assembly and achieve the scientific objectives. The bit was pulled above the mudline at 0100 on 11 May and Hole 461 was abandoned.

The profile records were reviewed and a new location, with offsets of $800 \mathrm{ft}$ south and $600 \mathrm{ft}$ east of the beacon, was selected. The drill pipe was run back and a mudline core attempt was spudded in Hole 461A at 0313 on 11 May. A six-meter core established bottom at 7044 meters which was the same as was calculated by using the PDR data. A second core was drilled to 15 meters and required 46 minutes and recovered 1.29 meters of pebbly to coarse-grained, igneous material. When the third core was attempted, fill was encountered at six meters and after 20 minutes the bit only reached a subbottom depth of 9 meters.

Since drilling difficulties had in no way eased, and there was no immediate protection for the drilling assembly, we decided that this hole also should be abandoned. At 0836, the mudline was cleared and the drill string was pulled. The hole was abandoned at 2136 on 11 May, when the bit reached the derrick floor. The Glomar Challenger then headed for Guam.

\section{BIOSTRATIGRAPHIC ZONATIONS}

Biostratigraphic zonations and age determinations are based mainly on calcareous nannoplankton and radiolarians. Rarely occurring, poorly preserved foraminifers provide supporting evidence at a few of the sites, and ichthyoliths (fish remains) provide supplementary evidence for age determinations at Site 452 . Post-cruise studies of foraminifers and ichthyoliths by V. A. Krasheninnikov and P. S. Doyle, respectively, are gratefully acknowledged by the shipboard paleontologists (Ellis and Kling).

Cretaceous radiolarians can be recovered from cherts at Site 452, and Cretaceous radiolarians and calcareous nannoplankton are seen in sediments collected from the western wall of the Mariana Trench at Sites 460 and 461. None of the in-place sediment sequences overlying basalt at the sites west of the Mariana Trench is older than late Eocene. The nannoplankton and radiolarian zonation schemes, together with absolute age assignments used in Leg 60 biostratigraphic determinations, are illustrated in Figure 8.

Quaternary radiolarian zones are from Nigrini (1971), and the Tertiary zones are from Riedel and Sanfilippo (1978). Absolute ages for the Quaternary are from Johnson and Knoll (1975); for the Miocene and Pliocene, from Theyer et al. (1978); and for the Oligocene and Eocene, from Bukry et al. (1973), Vincent (1974), and Hardenbol and Berggren (1978). Calcareous nannoplankton zonation and absolute age determinations are from Bukry $(1973,1975)$, Ellis and Lohman (1979), and Ellis (in press).

Leg 60 is the continuation of a transect made across the northern Philippine Sea that was begun on Leg 59. Different nannoplankton zonation schemes (Martini, Leg 59, in press, and Ellis, Leg 60, this volume) are used on the two legs. A comparison of the two schemes relating to absolute time is shown in Figure 9, so that biostratigraphic results from the two legs can be correlated. The time reference used in this figure is modified from Bukry (1975) and is consistent throughout this volume. It differs slightly from the one used on Leg 59 by Martini; however, the relationships of the various zones to one another between the two zonation schemes remain the same.

\section{EXPLANATORY NOTES}

\section{Site Chapter Organization}

The sites drilled on Leg 60 can be grouped into three distinct structural and tectonic groupings as follows:

1) the Pacific plate-west Mariana Basin (Site 452); 

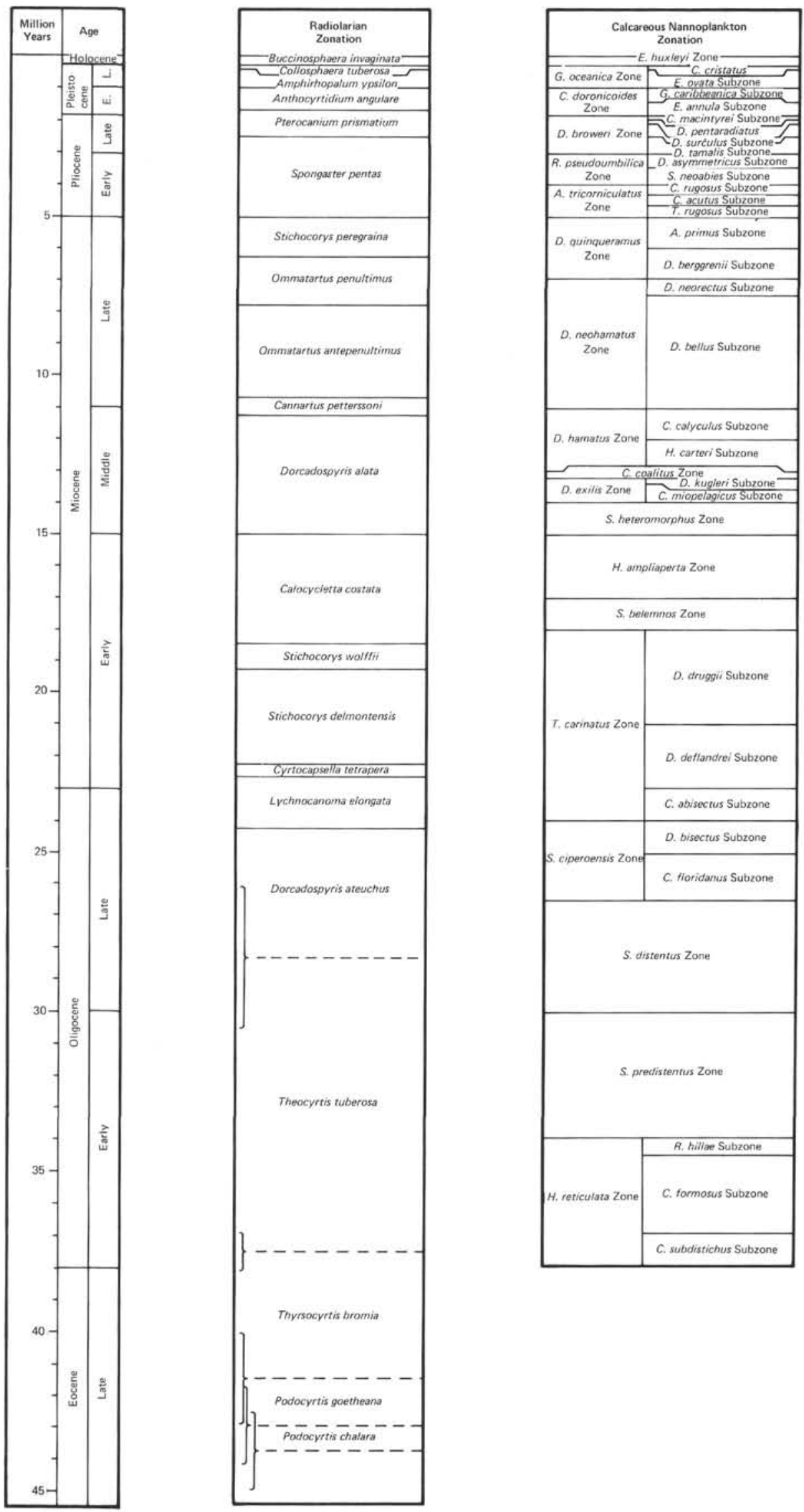

Figure 8. Leg 60 radiolarian and calcareous nannoplankton zonation related to absolute time. 


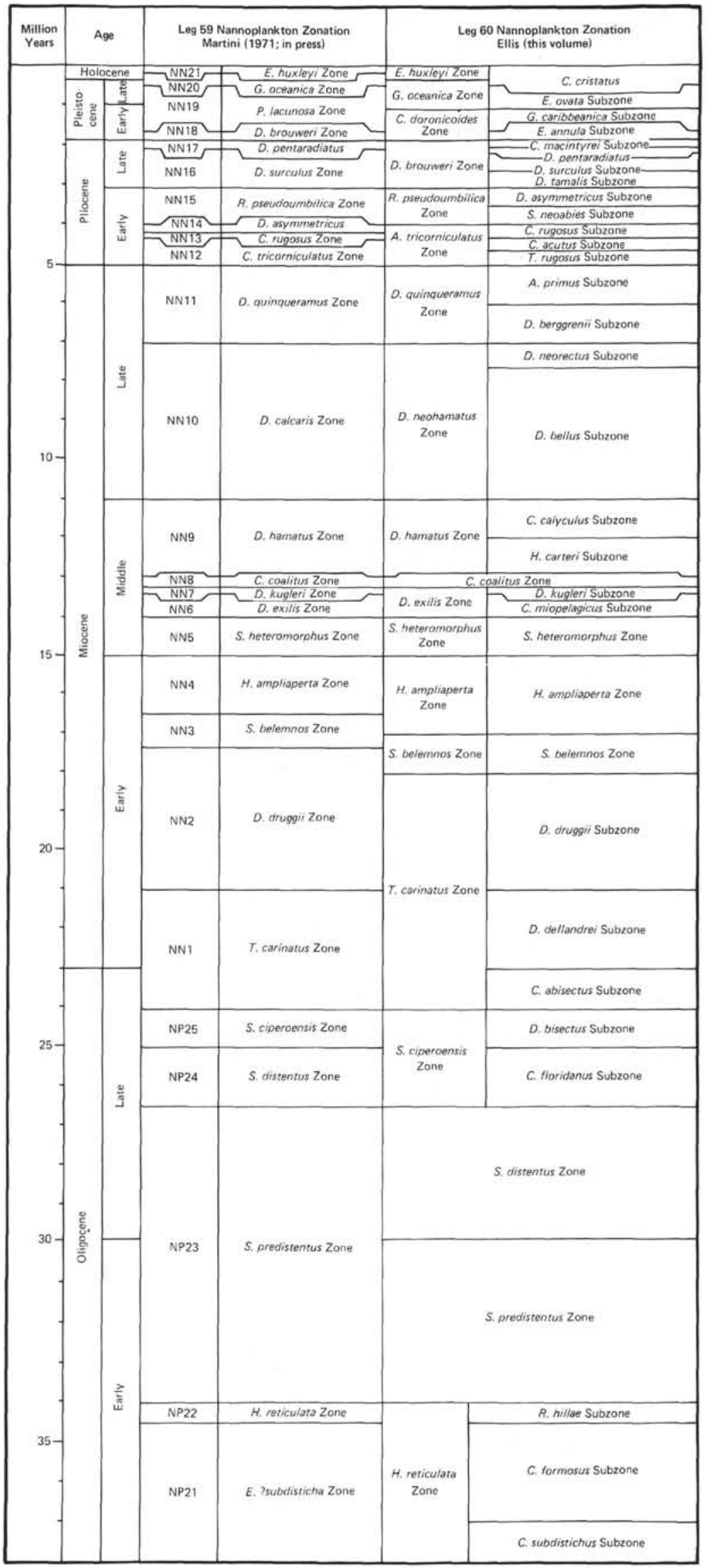

Figure 9. Comparison of calcareous nannoplankton zonation used on Leg 60 with that used on Leg 59. 
2) the Mariana Trough (Sites 453, 454, 455, and 456); and

3) the Mariana arc, fore-arc, and trench (Sites 457, $458,459,460$, and 461 ).

Because the last two of these groupings consist of several sites which had a unified suite of objectives, we have written separate background and objectives chapters for each, which precede the site chapters for Sites 453 and 457, respectively, in the table of contents. Apart from these two special chapters, the site chapters have been presented in a conventional format, and in the order they were drilled.

\section{Authorship Responsibilities}

The background, objectives, operations, and summary and conclusions sections were written by D. M. Hussong and S. Uyeda, with input from the rest of the shipboard scientific party. The lithologic summaries, accumulation rates, and stratigraphic syntheses were written by G. Packham, R. Blanchet, and K. Nakamura. Sections on biostratigraphy were written by $\mathrm{C}$. H. Ellis and S. Kling. The sections on paleomagnetism, interstitial water chemistry, thermal conductivity, and heat flow were abstracted from more comprehensive papers in this volume by U. Bleil, J. Gieskes, K. Horai, and S. Uyeda and K. Horai, respectively. Sections on igneous and metamorphic rocks were written by P. Fryer, A. Meijer, J. Natland, and A. Sharaskin. Information on the geochemistry of igneous and metamorphic rocks was abstracted from the paper and data of Wood et al. (this volume). These data were obtained in lieu of shipboard X-ray fluorescence data by special arrangement with John Tarney and colleagues at the University of Birmingham, Birmingham, England. Logging and the electrical resistivity experiment were successfully completed at Sites 454 and 459. Discussion of the results, as well as of standard shipboard physical properties measurements for all the sites, was written for the site chapters by $\mathrm{T}$. Francis.

\section{SHIPBOARD SCIENTIFIC PROCEDURES}

\section{Numbering of Sites, Holes, Cores, and Samples}

DSDP drill sites are numbered consecutively from the first site drilled by Glomar Challenger in 1968. Site numbers are slightly different from hole numbers. A site number refers to one or more holes drilled while the ship was positioned over one acoustic beacon. These holes could be located within a radius as great as 900 meters from the beacon. Several holes may be drilled at a single site by pulling the drill pipe above the seafloor (out of one hole) and moving the ship 100 meters or more from the previous hole, and then begin drilling another hole.

The first (or only) hole drilled at a site takes the site number. A letter suffix distinguishes each additional hole at the same site. For example: the first hole takes only the site number; the second takes the site number with suffix A; the third takes the site number with suffix $\mathrm{B}$; and so forth. It is important, for sampling purposes, to distinguish the holes drilled at a site, since recovered sediments or rocks from different holes usually do not come from equivalent positions in the stratigraphic column.

The cored interval is measured in meters below the seafloor. The depth interval of an individual core is the depth below seafloor that the coring operation began to the depth that the coring operation ended. Each coring interval is generally 9.5 meters long, which is the nominal length of a core barrel; however, the coring interval may be shorter or longer (rare). "Cored intervals" are not necessarily adjacent to each other, but may be separated by "drilled intervals." In soft sediment, the drill string can be "washed ahead" with the core barrel in place, but not recovering sediment, by pumping water down the pipe at high pressure to wash the sediment out of the way of the bit and up the space between the drill pipe and wall of the hole; however, if thin hard rock layers are present then it is possible to get "spotty" sampling of these resistant layers within the washed interval, and thus have a cored interval greater than 9.5 meters.

Cores taken from a hole are numbered serially from the top of the hole downward. Core numbers and their associated cored interval in meters below the seafloor are normally unique for a hole; however, problems may arise if an interval is cored twice. When this situation occurs, the core number is assigned a suffix, such as "S" for supplementary.

Full recovery for a single core is normally 9.28 meters of sediment or rock, which is in a plastic liner $(6.6 \mathrm{~cm}$ I.D.), plus about a 0.2 -meter-long sample (without a plastic liner) in the Core Catcher. The Core Catcher is a device at the bottom of the core barrel which prevents the cored sample from sliding out when the barrel is being retrieved from the hole. The sediment-core, which is in the plastic liner, is then cut into 1.5 meter-long sections and numbered serially from the top of the sediment-core (Fig. 10). When we obtain full recovery, the sections are numbered from 1 through 7 with the last section possibly being shorter than 1.5 meters. The Core-Catcher sample is placed below the last section when the core is described, and labeled Core-Catcher (CC); it is treated as a separate section. ${ }^{8}$

When recovery is less than 100 percent, and if the sediment or rock is contiguous, the recovered sediment is placed in the top ${ }^{9}$ of the cored interval, and then 1.5-meter-long sections are numbered serially, starting with Section 1 at the top. There will be as many sections as needed to accommodate the length of the core recovered (Fig. 10); for example, 3 meters of core sample in plastic liners will be divided into two 1.5-meter-long sections. Sections are cut starting at the top of the recovered sediment, and the last section may be shorter than the normal 1.5-meter length.

When recovery is less than 100 percent, the sediment's original stratigraphic position in the cored inter-

\footnotetext{
${ }^{7}$ Note that this designation has been used on previous legs as a prefix to the core number for sidewall core samples.

8 This procedure is followed for sediments only. For basalts, the Core-Catcher sample is incorporated into and given the number of the last section.

9 This technique differs from the labeling system used on Legs 1 through 45 , which had a designation called "zero section," but did not have a "number 7 section."
} 


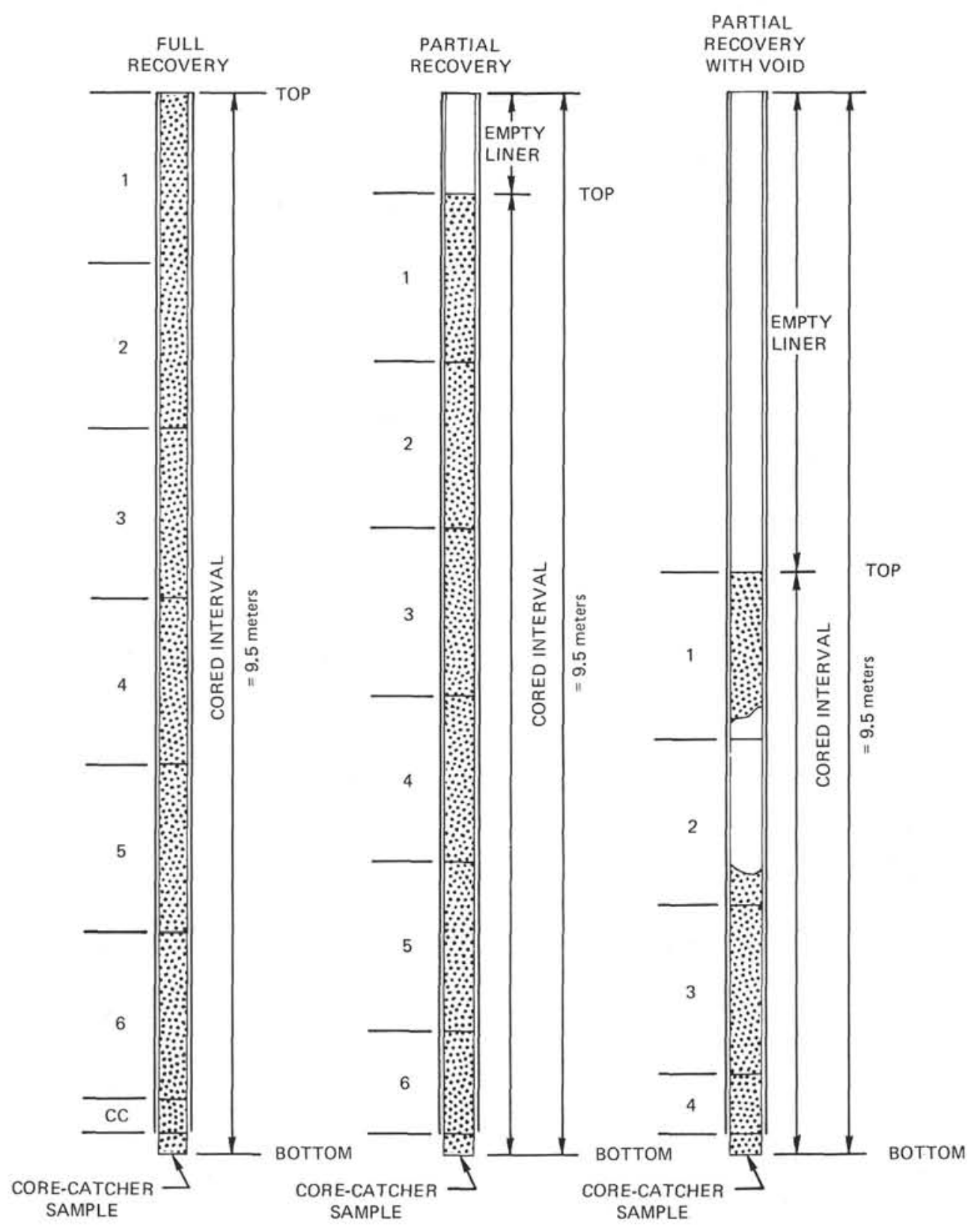

Figure 10. Labeling of sections for various kinds of recovery.

val is unknown, so we employ the convention of assigning the top of the sediment recovered to the top of the cored interval. This is done for convenience in data handling and consistency. If recovery is less than 100 percent and core fragments are separated, and if shipboard scientists believe the sediment was not contiguous, then sections are numbered serially and the intervening sections are noted as void, whether contiguous or not. The Core-Catcher sample is described in the Visual Core Descriptions beneath the lowest section.

Samples are designated by centimeter distances from the top of each section to the top and bottom of the sample in that section. A full identification number for a sample consists of the following information:
Leg,

Site,

Hole,

Core Number, and

Interval in centimeters from the top of section.

For example, a sample identification number of 60 459B-2-3, 12-14 cm is interpreted as follows: 12 to 14 $\mathrm{cm}$ designates a sample taken at 12 to $14 \mathrm{~cm}$ from the top of Section 3 of Core 2, from the third hole drilled at Site 459 during Leg 60 . A sample from the Core-Catcher of this core is designated as $60-459 \mathrm{~B}-2, \mathrm{CC}, 12-14 \mathrm{~cm}$.

The depth below the seafloor for a sample numbered $60-459 \mathrm{~B}-2-3,12-14 \mathrm{~cm}$ is the summation of the following: (1) the depth to the top of the cored interval for 
Core 2, which is 74 meters; (2) plus 3 meters for Sections 1 and 2 (each 1.5 meters long); plus the $12 \mathrm{~cm}$ depth below the top of Section 3. All of these variables add up to 77.12 meters, ${ }^{10}$ which theoretically is the sample depth below the seafloor.

\section{Handling of Cores}

A core was normally cut into 1.5 -meter sections, sealed, and labeled; the sections were then brought into the core laboratory for processing. The following determinations were normally made before the sections are split: gas analysis, thermal-conductivity analysis (soft sediment only), and continuous wet-bulk density determinations using the gamma ray attenuation porosity evaluation (GRAPE).

The cores were then split longitudinally into "working" and "archive" halves. Samples extracted from the "working"' half included those for grain size analysis, determination of mineralogy by X-ray diffraction, measurement of sonic velocity by Hamilton Frame method, measurement of wet-bulk density by a GRAPE method, measurement of water content by gravimetric analysis, carbon-carbonate analysis, measurement of calcium carbonate percentage (carbonate bomb), geochemical analysis, paleontological studies, and other studies.

Smear slides from each major lithology, and most minor lithologies, were prepared and examined microscopically. The archive half was then described and photographed. Physical disturbance by the drill bit, color, texture (for uncemented lithologies), sedimentary structure, and composition $( \pm 20 \%)$ of the various lithologies were noted on standard visual-core-description sheets.

After the cores were sampled and described, they were maintained in cold storage aboard the Glomar Challenger until transferred to the DSDP repository. Core sections which were removed for organic-geochemistry study were frozen immediately aboard ship and kept frozen. All Leg 60 cores and frozen cores are presently stored at the DSDP West Coast Repository (Scripps Institution of Oceanography).

Visual core descriptions, smear-slide descriptions, carbonate-bomb $\left(\% \mathrm{CaCO}_{3}\right)$ determinations (all done aboard ship), grain size analyses, carbon-carbonate determinations (both done at the DSDP shorebased laboratory), and X-ray diffraction data (from the labs of German Müller, Universität Heidelberg) provide the data for the core descriptions in this volume. This information is summarized and sample locations in the core are indicated on the core-description sheets (Fig. 11).

\section{SEDIMENT DESCRIPTION CONVENTIONS}

\section{Drilling Disturbance}

Recovered rocks, particularly soft sediments, may be extremely disturbed. This mechanical disturbance is a result of the coring technique, which uses a 25 -cm-diam-

\footnotetext{
${ }^{10}$ Sample requests should refer to a specific interval within a core-section, rather than the level below seafloor.
}

eter bit with a $6.0-\mathrm{cm}$ diameter opening for the core sample. The following disturbance categories are used for soft and firm sediment. These categories will be indicated on the core-description sheet (in a column) by coded patterns to which the key is in Figure 11. The categories are as follows:

Slightly disturbed: bedding contacts are slightly bent.

Moderately disturbed: bedding contacts have undergone extreme bowing.

Very disturbed: bedding is still more disturbed, sometimes showing symmetrical, diapir-like structures.

Soupy: sediment is water-saturated and original bedding is completely lost.

\section{Sedimentary Structures}

In the soft, and even in some harder sedimentary cores, it may be extremely difficult to distinguish between natural structures and structures created by the coring process. A column on the core-description sheet (Fig. 11) may have patterns (coded symbols) to indicate typical structures. The key to the set of structure-symbol codes is in Figure 12.

\section{Color}

Colors of the geologic material were determined with a Munsell or Geological Society of America Rock-Color Chart, immediately after the cores were split and while they were wet.

\section{Lithology}

The core-description sheets include a graphic lithologic column. The symbols used in this column are explained in Figure 13. Often a single lithology will be represented in the column by a single pattern. Some lithologies are represented by a combination of two or more symbols. The symbols in this combination may correspond to end-member sediment constituents, such as clay and nannofossil ooze. Normally the symbol for the dominant constituent is placed on the right-hand side of the column, and the symbol for the subordinate constituent will be on the left-hand side of the column (see examples in Fig. 13). The proportions of the components are represented in the graphic column by the relative widths of the symbols. For example, the left 20 percent of the column may have a clay symbol, while the right 80 percent of the column may have a nannofossil ooze symbol. This means that the core-interval is approximately 80 percent nannofossil ooze and 20 percent clay. The vertical lines which separate the symbols are shown in Figure 11 with their corresponding percentages and positions in the column.

\section{Core Description}

Format, style, and terminology of the descriptive portion of the core-description sheets (Fig. 11) are not controlled by the "Mandatory Graphic Lithologic Column Scheme," beyond the minimal name assignment which is derived from the lithologic classification (described below). Colors and additional information such as structure and textures, are normally included in the text portion of the core description. 


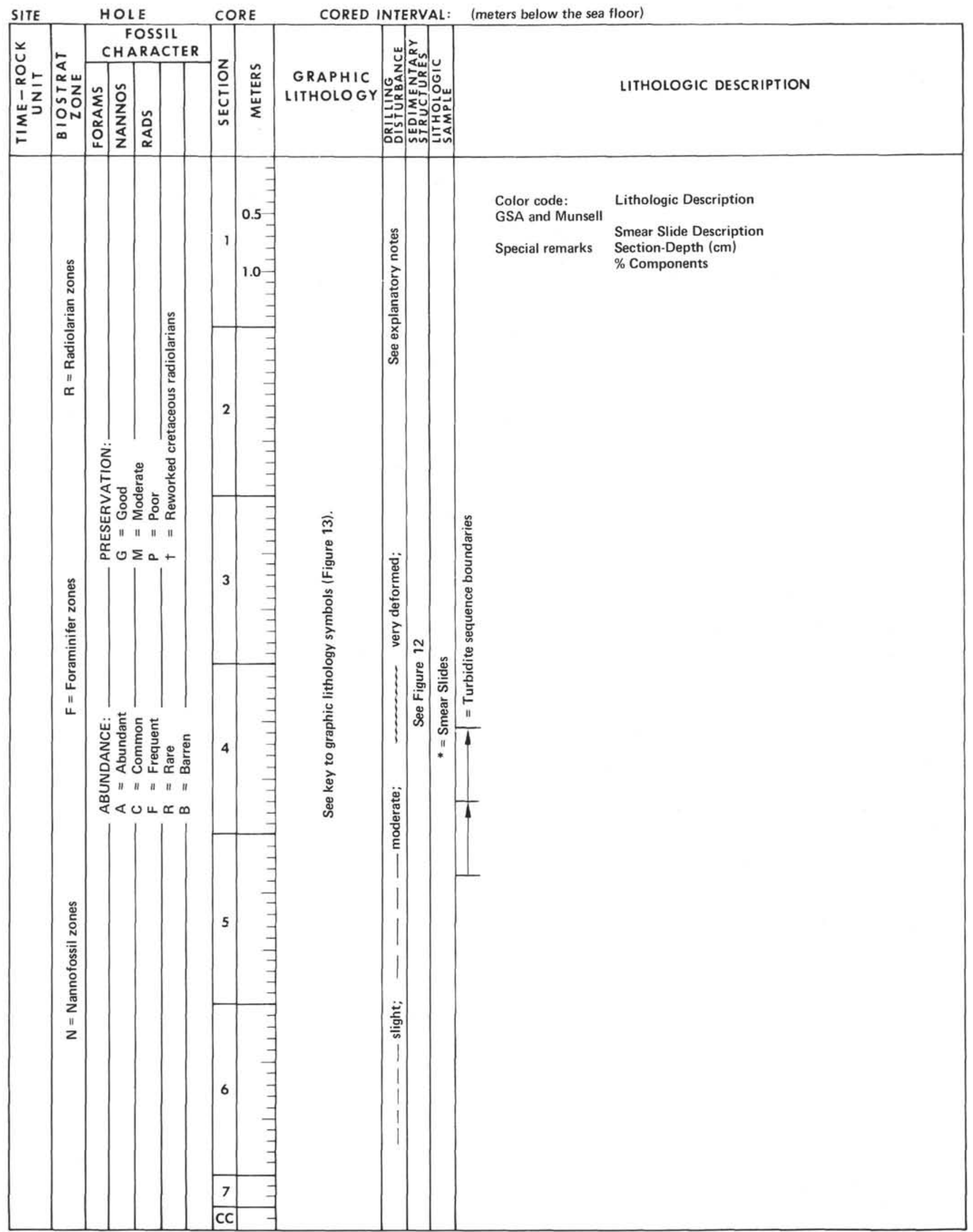

Figure 11. Sample core form (sediment). 


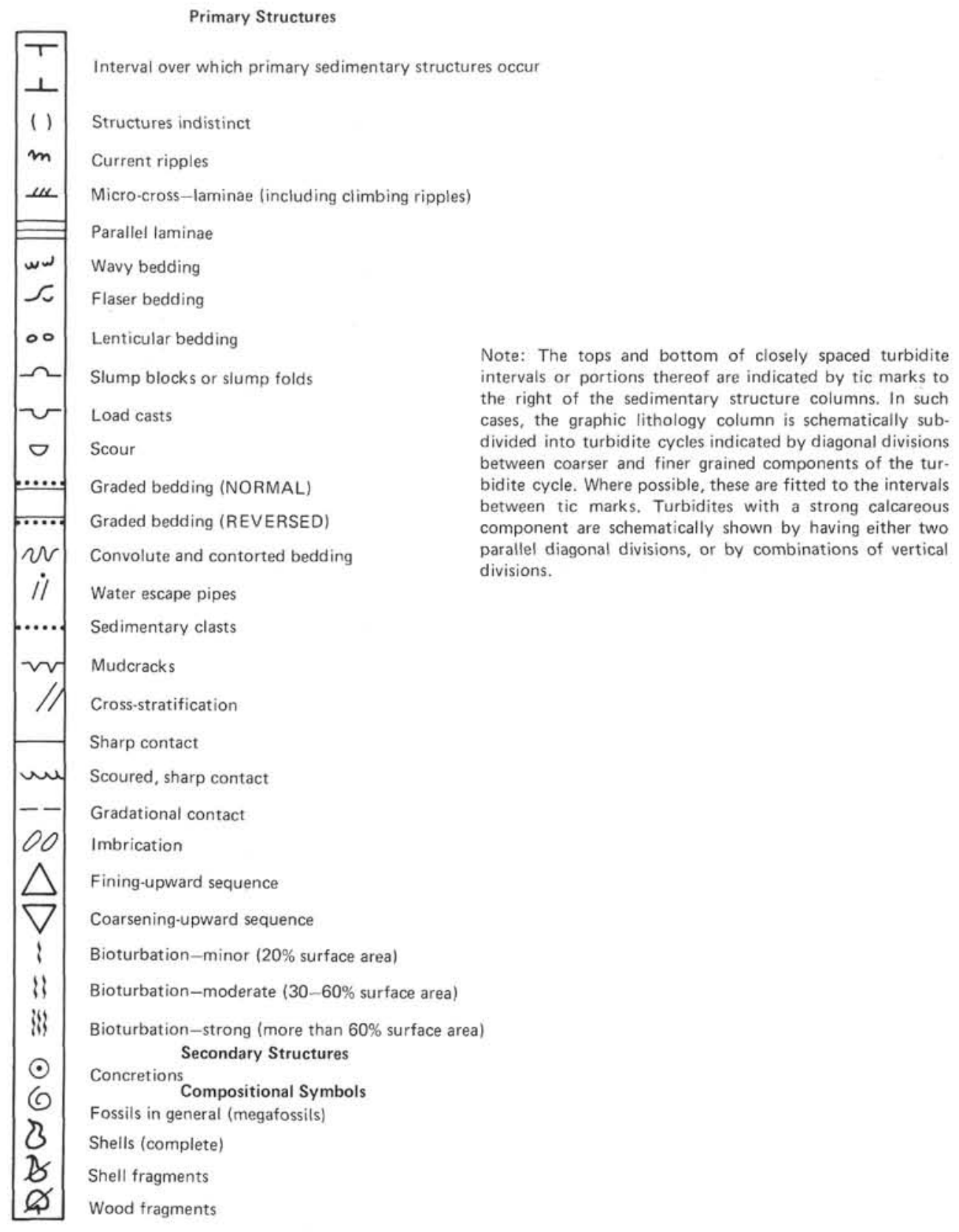

Figure 12 . Sedimentary structure symbols.

\section{SEDIMENT CLASSIFICATION}

The sediment classification is basically that devised by the JOIDES Panel on Sedimentary Petrology and Physical Properties (SPPP) and adopted with minor modifications by the JOIDES Planning Committee in March 1974.

\section{General Principles}

This classification is not comprehensive; therefore, a category of "Special Rock Types"' will create additional definitions and terminology of rock types not covered. The classification is descriptive, and genetic implications are not intended. These divisions are naturally artificial, and the proposed classification is only a rough grouping of what we really find in nature. The classification, as used in this volume, will use data that were primarily estimated or measured aboard the ship.

1. General rules for class limits and order of components present in a sediment name.

a) Sediment assumes only the names of those components present in quantities greater than 15 percent.

b) Where more than one component is present, the component in greatest abundance is listed farthest to the right, and other components are listed progressively to the left in order of decreasing abundance.

c) The class limits are based on percentage intervals given below for various sediment types. 
Pelagic

Nonbiogenic

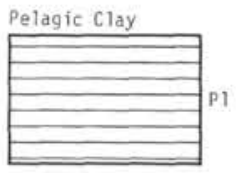

Siliceous Biogenic

Pelagic Siliceous Biogenic - Soft

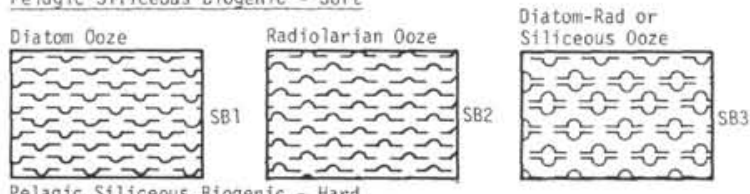

Pelagic Siliceous Biogenic - Hard

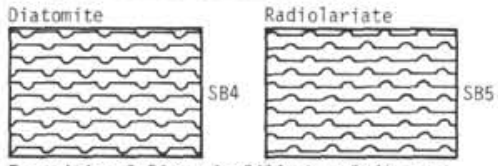

Iransitionat Biogenic Silfceous Sediments

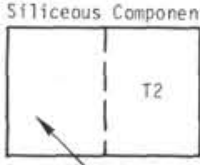

(2.

Yertical par percent

(2) Designation

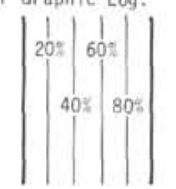

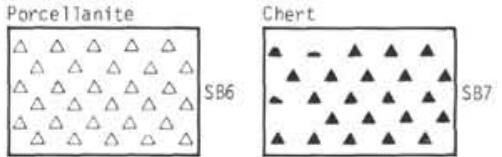

S11iceous Coriponent $>504$

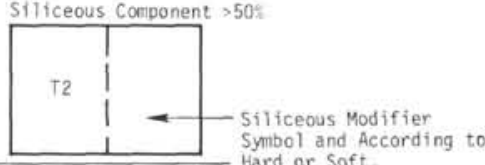

Calcareous Biogenic

Pelagic Biogenic Calcareous - Soft

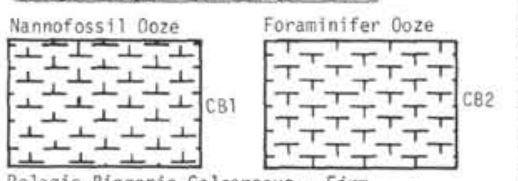

Pelagic Biogenic Calcareous - Firm

Nannofossil Chalk

Pelagic Blogenic Calcareous - Hard

Limestone

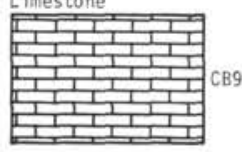

Terrigenous Sediments

Clay/Claystone

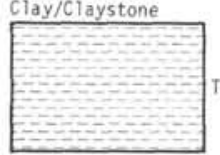

Silty Sand/

Sandy Silt

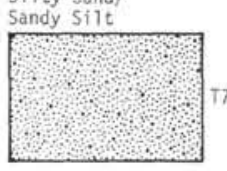

Pyroclastic

Volcanic Ash $\quad$ Volcanic Lapilli

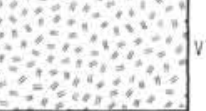

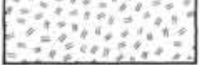

Special Rock Types

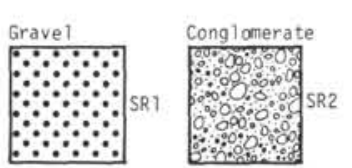

Figure 13. Graphic symbols to accompany the lithologic classification scheme.
Nanno-Foram or

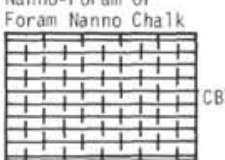

Iransitional Biogenic

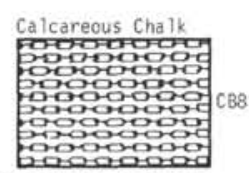

CB8
Symbols which may be used for any

new additions to the present

sediment/rock groups. Assign

with present system.
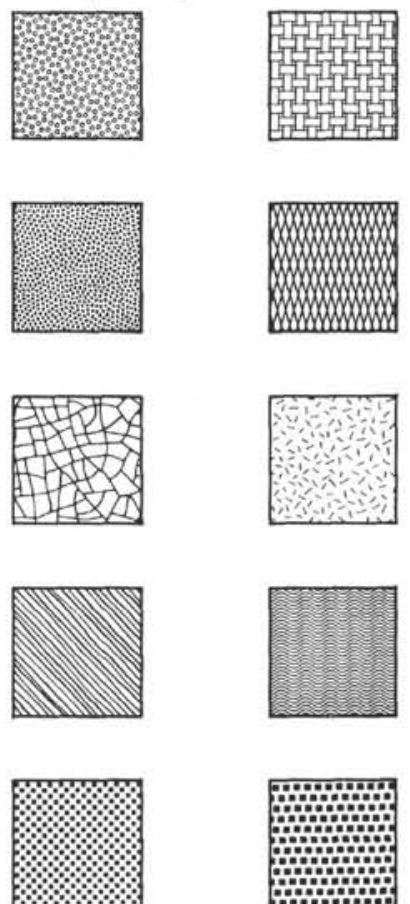

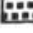


2. Compositional class boundaries.

a) $\mathrm{CaCO}_{3}$ content (determined by carbonate bomb). Class boundaries of 30 and 60 percent. Given the natural frequency distribution of $\mathrm{CaCO}_{3}$ contents in oceanic sediments, these boundaries can be ascertained with a precision of 5 percent.

b) Biogenic-opal abundance. Expressed as percent siliceous remains in smear slides. Class boundaries at 10, 30, and 50 percent. Smearslide estimates of identifiable siliceous skeletal material generally imply a significantly higher total opal abundance. The boundaries have been set to take this into account.

c) Abundance of authigenic components. Zeolites, Fe and $\mathrm{Mn}$ micronodules, fish bones, and other indicators of very slow sedimentation (estimated in smear slides); semiquantitative boundary; common 10 percent. These components are very conspicuous, and a semiquantitative estimate is adequate. Even a minor influx of calcareous, siliceous, or terrigenous material will dilute them to insignificance because of the large difference in sedimentation rate.

d) Abundance of terrigenous detrital material. Estimated from smear slides: 30 percent.

e) Qualifiers. Numerous qualifiers are suggested; the options should be used freely. However, components of less than 5 percent (in smear slide) should not be used as a qualifier except in special cases.

\section{Descriptive Data}

Sediment and rock names are defined solely on the basis of composition and texture. Composition is most important for description of those deposits more characteristic of open marine conditions, with texture becoming more important for the classification of hemipelagic and nearshore facies. These data are primarily determined aboard ship by visual estimates "in smear slides" with the aid of a microscope.

\section{Smear Slides}

The lithologic classification of sediments is based on visual estimates of texture and composition in smear slides made aboard ship. These estimates are of areal abundances on the slide and may differ somewhat from the more accurate laboratory analyses of grain size, carbonate content, and mineralogy. Experience has shown that distinctive minor components can be accurately estimated $( \pm 1-2 \%)$, but that an accuracy of \pm 10 percent for major constituents is rarely attained. Carbonate content is especially difficult to estimate in smear slides, as is the amount of clay present. The locations of smear slides made are given on the core-description sheets.

\section{Sediment Induration}

The determination of induration is highly subjective, but field geologists have successfully made similar dis- tinctions for many years. The criteria of Gealy et al. (1971) are used for calcareous deposits; subjective estimate or behavior in core cutting is used for others.

A. Calcareous Sediments

Soft: Oozes have little strength and are readily deformed under the finer or the broad blade of a spatula.

Firm: Chalks are partly indurated oozes; they are friable limestones that are readily deformed under the fingernail or the edge of a spatula blade.

Hard: Cemented rocks are termed limestones.

B. The following criteria are used for other sediments:

1. If the material is soft enough for the core to be split with a wire cutter, the sediment name only is used (e.g., silty clay; sand).

2. If the core must be cut on the band saw or diamond saw, the suffix "stone" is used (e.g., silty claystone; sandstone).

\section{Description of Sediment Types}

\section{Pelagic Clay}

Principally authigenic pelagic deposits that accumulate at very slow rates. The class is often termed brown clay, or red clay, but since these terms are confusing, they are not recommended.

1. Boundary with Terrigenous Sediments.

Where authigenic components ( $\mathrm{Fe}$ and $\mathrm{Mn}$ micronodules, zeolites), fish debris, etc., become common in smear slides. Note: Because of large discrepancy in accumulation rates, transitional deposits are exceptional.

2. Boundary with Siliceous Biogenic Sediments. $<30$ percent identifiable siliceous remains.

3. Boundary with Calcareous Biogenous Sediments.

Generally the sequence is one passing from pelagic clay through siliceous oozes to calcareous ooze, with one important exception: at the base of many oceanic sections, black, brown, or red clays occur directly on basalt, overlain by or grading up into calcareous sediments. Most of the basal clayey sediments are rich in iron, manganese, and metallic trace elements. For proper identification, they require more elaborate geochemical work than can be done on shipboard. These sediments are placed in the "Special Rock" category, but care should be taken to distinguish them from ordinary pelagic clays.

\section{Pelagic Siliceous Biogenic Sediments}

These are distinguished from the previous category because they have more than 30 percent identifiable siliceous microfossils. They are distinguished from the following category by a $\mathrm{CaCO}_{3}$ content of less than 30 percent. There are two classes: pelagic biogenic siliceous sediments (containing less than $30 \%$ silt and clay), and transitional biogenic siliceous sediments (containing more than $30 \%$ silt and clay and more than $10 \%$ diatoms). 
1. Pelagic Biogenic Siliceous Sediments.

a. Soft: Siliceous ooze (radiolarian ooze, diatomaceous ooze, depending on dominant component).

b. Hard: Radiolarite, porcellanite, diatomite, and chert.

c. Qualifiers:

Radiolarians dominant-radiolarian ooze or radiolarite.

Diatoms dominant-diatom ooze or diatomite.

Where uncertain-siliceous (biogenic) ooze, chert, or porcellanite; when containing $>10$ percent $\mathrm{CaCO}_{3}$, qualifiers are as follows:

Indeterminate Carbonate: Calcareous.

Nannofossils Only: Nannofossil.

Foraminifers Only: Foraminifer.

Nannofossil-Foraminiferal. Depending on dominant component:

Foraminiferal-Nannofossil.

2. Transitional Biogenic Siliceous Sediments.

Diatoms $<50$ percent-diatomaceous mud (soft) or diatomaceous mudstone (hard).

Diatoms $>50$ percent-muddy diatom ooze (soft) or muddy diatomite (hard).

Radiolarian equivalents in this category are rare and can be specifically described.

\section{Pelagic Biogenous Calcareous Sediments}

These are distinguished from the previous categories by a $\mathrm{CaCO}_{3}$ content in excess of 30 percent. There are two classes: Pelagic biogenic calcareous sediments (containing less than $30 \%$ silt and clay), and transitional biogenic calcareous sediments (containing more than $30 \%$ silt and clay).

1. Pelagic Biogenic Calcareous Sediments

a. Soft: calcareous ooze.

b. Firm: chalk.

c. Hard: indurated chalk.

The term limestone should be restricted to cemented rocks.

d. Compositional Qualifiers:

Principal components are nannofossils and foraminifers. One or two qualifiers may be used, for example:

\begin{tabular}{cl}
\hline $\begin{array}{c}\text { Foraminifers } \\
(\%)\end{array}$ & \multicolumn{1}{c}{ Name } \\
\hline$<10$ & Nannofossil ooze, chalk, limestone. \\
$10-25$ & Foraminifer-nannofossil ooze. \\
$25-50$ & Nannofossil-foraminifer ooze. \\
$>50$ & Foraminifer ooze. \\
\hline
\end{tabular}

Calcareous sediment containing more than 10 to 20 percent identifiable siliceous fossils carry the qualifier "radiolarian," "diatomaceous," or "siliceous," depending on the quality of the identification - for example, "radiolarian-foraminifer ooze."

2. Transitional Biogenic Calcareous Sediments.

a. $\mathrm{CaCO}_{3}, 30$ to 60 percent: Marly calcareous pelagic sediments.
Soft: Marly calcareous (or nannofossil, foraminifer, etc.) ooze (see below).

Firm: Marly chalk.

Hard: Marly limestone.

b. $\mathrm{CaCO}_{3}>60$ percent: Calcareous pelagic sediments.

Soft: Calcareous (or nannofossil, foraminiferal, etc.) ooze (see below).

Firm: Chalk.

Hard: Limestone.

Note: Sediments containing 10 to 30 percent $\mathrm{CaCO}_{3}$ fall in other classes where they are denoted with the adjective "calcareous." Less than 10 percent $\mathrm{CaCO}_{3}$ is ignored.

\section{Terrigenous Sediments}

Terrigenous sediments are distinguished by a terrigenous component in excess of 30 percent, and siliceous and authigenic components each less than 10 percent.

Sediments in this category are subdivided into textural groups (by smear slide estimation or grain size analysis) on the basis of the relative proportions of sand, silt, and clay. The size limits are those defined by Wentworth (1922). Textural classification follows the triangular diagram of Shepard (1954).

The transition between pelagic and terrigenous sediments is termed hemipelagic.

\section{Volcanogenic Sediments}

Sediments rich in volcaniclastic material (most commonly volcanic glass) have not received detailed attention in the previous classification devised by the JOIDES Panel on Sedimentary Petrology and Physical Properties and adopted for use by the JOIDES Planning Committee in March 1974-hereafter designated as "JOIDES classification."

The JOIDES classification follows the Wentworth and Williams proposal of 1932, which is concerned almost exclusively with subaerial pyroclastic material and does not coincide with sediments rich in volcaniclastic material.

The textural groups of Wentworth and Williams (1932) are:

$>32 \mathrm{~mm}$-Volcanic breccia.

$32 \mathrm{~mm}-4 \mathrm{~mm}-$ Volcanic lapilli.

$<4 \mathrm{~mm}-$ Volcanic ash (tuff when indurated).

In the western Pacific area, sediments rich in volcaniclastic material occupy a significant portion of the drilled cores. A classification scheme adopted by the Shipboard Scientific Party of Leg 58 is as follows:

\begin{tabular}{cll}
\hline \multicolumn{3}{c}{ Description of Sedimentary Rocks Rich in Ash (Leg 58 scheme) } \\
$\%$ Ash & Not Indurated & \multicolumn{1}{c}{ Indurated } \\
\hline $0-10$ & Mud & Mudstone \\
$10-30$ & Vitric Mud & Vitric Mudstone \\
$30-60$ & Muddy Ash & Tuffite \\
$60-100$ & Ash & Tuff \\
\hline
\end{tabular}

We have not employed this scheme on Leg 60 for the following reasons: 
1. Tuffite is a new term to the current JOIDES classification.

2. Sandy and clayey volcaniclastics are not covered.

3. The term ash (tuff) is used as a synonym of glass (vitric tuff).

On Leg 59, another scheme, one both descriptive and non-genetic, was used to describe considerable thicknesses of bedded, often quite coarse, volcaniclastic sediments and rocks (Table 3 ).

Although this covers ranges in grain size and some specifics on rounding and sorting, it does not cover sandy and clayey volcaniclastics. It does deal more specifically with the composition of ash.

Regarding the use of the term "ash," ash (tuff when indurated) refers only to size, and not to composition (Williams et al., 1954, p. 149). Ash or tuff can be composed dominantly of crystals as well as volcanic glass, or rock fragments. We propose to retain the usage of the terms ash and tuff for predominantly volcaniclastic sediments of any origin-that is, pyroclastic, hyaloclastic, and epiclastic.

With the above statement in mind and after the experience gained on Leg 60, we have adopted the following classification for sediments rich in ash-sized volcaniclastics:

\begin{tabular}{ccc}
\hline \multicolumn{3}{c}{ Classification of Sediments and Rocks Rich in Ash (Leg 60 scheme) } \\
\hline$\%$ Ash & \multicolumn{1}{c}{ Not Indurated } & \multicolumn{1}{c}{ Indurated } \\
\hline $0-10$ & $\begin{array}{l}\text { Same as terrigenous sediments and rocks (clay, } \\
\text { mudstone, and so forth). }\end{array}$ \\
$10-50$ & $\begin{array}{l}\text { Add qualifiers* as vitric, lithic, and crystals to ter- } \\
\text { rigenous sediment and rock names (vitric mud, } \\
\text { crystal sandy mudstone. . .). }\end{array}$ \\
50-100 \\
$\begin{array}{l}\text { Add qualifiers* as } \\
\text { (1) vitric, lithic and crystal } \\
\text { (2) sandy, muddy, silty. . . } \\
\text { (muddy crystal ash. . .) }\end{array}$ \\
\hline
\end{tabular}
* Only when they are over 10 percent of the material as viewed in
smear slides.

This scheme makes use of the grain-size divisions of the JOIDES classification listed previously, rather than those of the Leg 59 classification. Therefore, whereas volcaniclastics with size grade between 2 and $4 \mathrm{~mm}$ us- ing the Leg 60 classification are ash (tuff), using the Leg 59 classification they are gravels (breccias or conglomerates). For the most part, the Leg 60 volcaniclastic sediments have size grade $<2 \mathrm{~mm}$, hence are essentially equivalent to Leg 59 ashes (tuffs). The designation fine ash (tuff) was not used on Leg 60.

The three schemes used on Legs 58 through 60 are listed here to assist anyone who wishes to compare sediments from any of these three closely related legs.

\section{Qualifiers}

In general, sediments containing various constituents in the 10 to 30 percent range may be identified in the name of sediment such as vitric diatomaceous mud or vitric muddy diatomaceous ooze. If more than one such qualifier is used, they are listed in order of increasing abundance in the sediment.

\section{Carbon-Carbonate and Grain-Size Analysis}

Samples were taken routinely for carbon-carbonate and grain-size analysis during Leg 60 . These, and shipboard carbonate bomb data, are listed on the barrel sheets and in Natland and Bode (this volume).

\section{BASEMENT-DESCRIPTION CONVENTIONS}

\section{Core Forms}

Core-description forms for igneous and metamorphic rocks are not the same as those used for sediments. The latter are essentially those published in previous "Initial Reports." Igneous rock representation on such sheets, however, is too compressed to provide adequate information for rock sampling. Consequently, visual-core description forms, modified from those used aboard ship, are used here for more-complete graphic representation. Each of these forms covers one 1.5-meter section. All shipboard chemical- and physical-property data, as well as summary hand-specimen and thin-section descriptions, are presented for each section.

All basalts were split with a rock saw into archive and working halves. The latter was described and sampled aboard ship. In a typical basalt description form (Fig. 14), the left box is a visual representation of the working half. Lithologies are indicated in the graphic representation column using symbols shown on Figure 15. Two

Table 3. Classification of volcaniclastic sediments (Leg 59 scheme).

\begin{tabular}{|c|c|c|c|c|}
\hline \multicolumn{2}{|c|}{ Size Graded } & Clast Rounding & Unconsolidated & Consolidated \\
\hline \multirow{4}{*}{$\phi>2 \mathrm{~mm}$} & \multirow{2}{*}{$\mathrm{C} / \mathrm{M}>2: 1$} & Predominantly Angular & \multirow{2}{*}{$\begin{array}{l}\text { Volcaniclastic Gravel } \\
\text { [add rounding modifier] }\end{array}$} & Volcaniclastic Breccia \\
\hline & & Predominantly Rounded & & Volcaniclastic Conglomerate \\
\hline & \multirow{2}{*}{$\mathrm{C} / \mathrm{M}<2: 1$} & Predominantly Angular & \multirow{2}{*}{$\begin{array}{l}\text { Ashy Volcaniclastic Gravel } \\
\text { [add rounding modifier] }\end{array}$} & Tuffaceous Volcaniclastic Breccia \\
\hline & & Predominantly Rounded & & Tuffaceous Volcaniclastic Conglomerate \\
\hline \multicolumn{2}{|c|}{$\phi 1 / 16-2 \mathrm{~mm}$} & & $\begin{array}{l}\text { Vitric } \\
\text { Crystal } \\
\text { Lithic }\end{array}$ & $\begin{array}{l}\text { Vitric } \\
\text { Crystal } \\
\text { Lithic }\end{array}$ \\
\hline \multicolumn{2}{|c|}{$\phi<1 / 16 \mathrm{~mm}$} & & $\begin{array}{l}\text { Vitric } \\
\text { Crystal } \\
\text { Lithic }\end{array}$ & $\begin{array}{l}\text { Vitric } \\
\text { Crystal } \\
\text { Lithic }\end{array}$ \\
\hline
\end{tabular}


closely spaced horizontal lines in this column indicate the location of styrofoam spacers taped between basalt pieces inside the liner. Each piece is numbered sequentially from the top of each section, beginning with the number 1 . Pieces are labeled on the rounded, not the sawed surface. Pieces which could be fit together before splitting are given the same number, but are lettered consecutively as "1A, 1B, 1C," etc. Spacers are placed between pieces with different numbers, but not between those with different letters and the same number. In general, addition of spacers represents a drilling gap (no recovery). All pieces which are cylindrical and longer than the liner diameter have orientation arrows pointing up, both on the archive and working halves. Special procedures were adopted to ensure that orientation was preserved through every step of the sawing and labeling process. All orientable pieces are indicated by upwardpointing arrows to the right of the graphic representation on the description forms. Because the pieces were rotated during drilling, it is not possible to sample for declination studies.

Samples were taken for various measurements aboard ship. The type of measurement and approximate location are indicated in the column headed "Shipboard Studies," using the following notation:

$\mathrm{X}=\mathrm{X}$-ray fluorescence and $\mathrm{CHN}$ chemical analysis.

$M=$ magnetics measurement.

$\mathrm{S}=$ sonic-velocity measurement.

$\mathrm{T}=$ thin section.

$\mathrm{D}=$ density measurement.

$\mathrm{P}=$ porosity measurement.

The state of alteration (see Fig. 15 for symbols) is shown in the column labeled "Alteration."

\section{Igneous and Metamorphic Rock Classification}

Basalts, metabasalts, andesites, and gabbros were recovered on Leg 60. Classification is based mainly on mineralogy of visible minerals in hand-specimen and in thin sections, and secondarily on texture. In the case of andesites at Site 458, a chemical qualifier (high-Mg andesite) was also used.

Volcanic rocks are termed aphyric, sparsely phyric, moderately phyric, or phyric, depending on the proportion of phenocrysts visible with the binocular microscope $(\sim \times 12)$. Volcanic rocks are termed aphyric if phenocrysts are absent. For practical purposes, this means that if one piece of basalt was found with a phenocryst or two in a section where all other pieces lack phenocrysts, and no other criteria (such as grain size or texture) distinguish this basalt from the others, then it too is described as aphyric. A note of the rare phenocrysts is included in the general description, however. This approach enables us to restrict the number of lithologic units to those with clearly distinctive and persistent visual differences.

Sparsely phyric volcanic rocks are those with 1 to 2 percent phenocrysts in almost every piece of a given core or section. Clearly contiguous pieces without phenocrysts are included in this category, the lack of phenocrysts again noted in the general description.
Moderately phyric volcanic rocks contain 2 to 10 percent phenocrysts. Aphyric basalts within a group of moderately phyric basalts are separately termed aphyric basalts.

Phyric volcanic rocks contain more than 10 percent phenocrysts. No separate designation is made for basalts with higher proportions of phenocrysts; the proportions indicated in the core forms should be sufficient to guide the reader.

Volcanic rocks are further classified by phenocryst type, and a modifying term precedes the terms phyric, sparsely phyric, etc. A plagioclase-olivine, moderately phyric basalt contains 2 to 10 percent phenocrysts, most of them plagioclase, but with some olivine.

Plutonic rocks recovered on Leg 60 are also described by mineralogy, except where separate rock names based on the mineralogy are in common usage.

Apart from the high-Mg andesites of Site 458, no petrochemical or normative classification schemes are used on the core forms. The reader is referred to the Site Summaries and Wood et al. (this volume) for information pertinent to this aspect of Leg 60 igneous rock classification.

\section{REFERENCES}

Bukry, D., 1973. Low-latitude coccolith biostratigraphic zonation. In Edgar, N. T., Saunders, J. B., et al., Init. Repts. DSDP, 15: Washington (U.S. Govt. Printing Office), 685-703.

, 1975. Coccolith and silicoflagellate stratigraphy, northwestern Pacific Ocean, Deep Sea Drilling Project, Leg 32. In Larson, R. L., Moberly, R., et al., Init. Repts. DSDP, 32: Washington (U.S. Govt. Printing Office), 677-701.

Bukry, D., Dinkelman, M. G., and Kaneps, A., 1973. Biostratigraphy of the equatorial East Pacific Rise. In van Andel, Tj. H., Heath, G. R., et al., Init. Repts. DSDP, 16: Washington (U.S. Govt. Printing Office), 915-935.

Ellis, C. H., in press. Neogene nannoplankton zonation in eastern Mediterranean. Proc. 8th Internat. Congress on Med. Neogene, Athens, 1979.

Ellis, C. H., and Lohman, W. H., 1979. Neogene calcareous nannoplankton biostratigraphy in eastern Mediterranean deep-sea sediments (DSDP Leg 42A, Site 375 and 376). Mar. Micropaleont., 4:61-84.

Gealy, E. L., Winterer, E. L., and Moberly, R., 1971. Methods, conventions and general observations. In Winterer, E. L., Riedel, W. R., Init. Repts. DSDP, 7, Pt. 1: Washington (U.S. Govt. Printing Office), 9-26.

Hardenbol, J., and Berggren, W. A., 1978. A new Paleogene numerical time scale. Am. Assoc. Petrol. Geol.: Studies in Geology, 6: 213-234.

Hobart, M. A., Anderson, R. N., and Uyeda, S., 1979. Heat transfer in the Mariana Trough. EOS, 60:383.

Johnson, D. A., and Knoll, A. H., 1975. Absolute ages of Quaternary radiolarian datum levels in the equatorial Pacific. Quat. Res., 5: 99-110.

Liou, J. E., 1971. P-T stabilities of laumontite, wairakite, lawsonite, and related minerals in the system $\mathrm{CaAl}_{2} \mathrm{SiO}_{2}-\mathrm{SiO}_{2}-\mathrm{H}_{2} \mathrm{O} . J$. Petrol., 12:379-411.

Martini, E., 1971. Standard Tertiary and Quaternary calcareous nannoplankton zonation. Proc. 2nd Plank. Conf., Rome, 2:738-785. , in press. Oligocene to recent calcareous nannoplankton from the Philippine Sea, DSDP Leg 59. In Kroenke, L., Scott, R., et al., Init. Repts. DSDP, 59: Washington (U.S. Govt. Printing Office), 547-566.

Nigrini, C. A., 1971. Radiolarian zones in the Quaternary of the equatorial Pacific. In Funnell, B. M., and Riedel, W. R. (Eds.), The Micropaleontology of Oceans: London (Cambridge University Press), pp. 443-461. 
Riedel, W. R., and Sanfilippo, A., 1978. Stratigraphy and evolution of tropical Cenozoic radiolarians. Micropaleontology, 24:61-96.

Shepard, F. P., 1954. Nomenclature based on sand-silt-clay ratios. J. Sediment. Petrol., 24:151-158.

Theyer, F., Mato, C. Y., and Hammond, S. R., 1978. Paleomagnetic and geochronological calibration of latest Oligocene to Pliocene radiolarian events, equatorial Pacific. Mar. Micropaleont., 3:377395.

Vincent, E., 1974. Cenozoic planktonic biostratigraphy and paleoceanography of the tropical western Indian Ocean. In Fisher,
R. L., Bunce, E. T., et al., Init. Repts. DSDP, 24: Washington (U.S. Govt. Printing Office), 1111-1150.

Wentworth, C. K., 1922. A scale of grade and class terms of clastic sediments. J. Geol., 30:377.

Wentworth, C. K., and Williams, H., 1932. The classification and terminology of the pyroclastic rocks. Rept. Comm. Sedimentation. Bull. Nat. Res. Covnc., 80:10-53.

Williams, H., Turner, F. J., and Gilbert, C. M., 1954. Petrography: An Introduction to the Study of Rocks in Thin Sections: San Francisco (W. H. Freeman). 


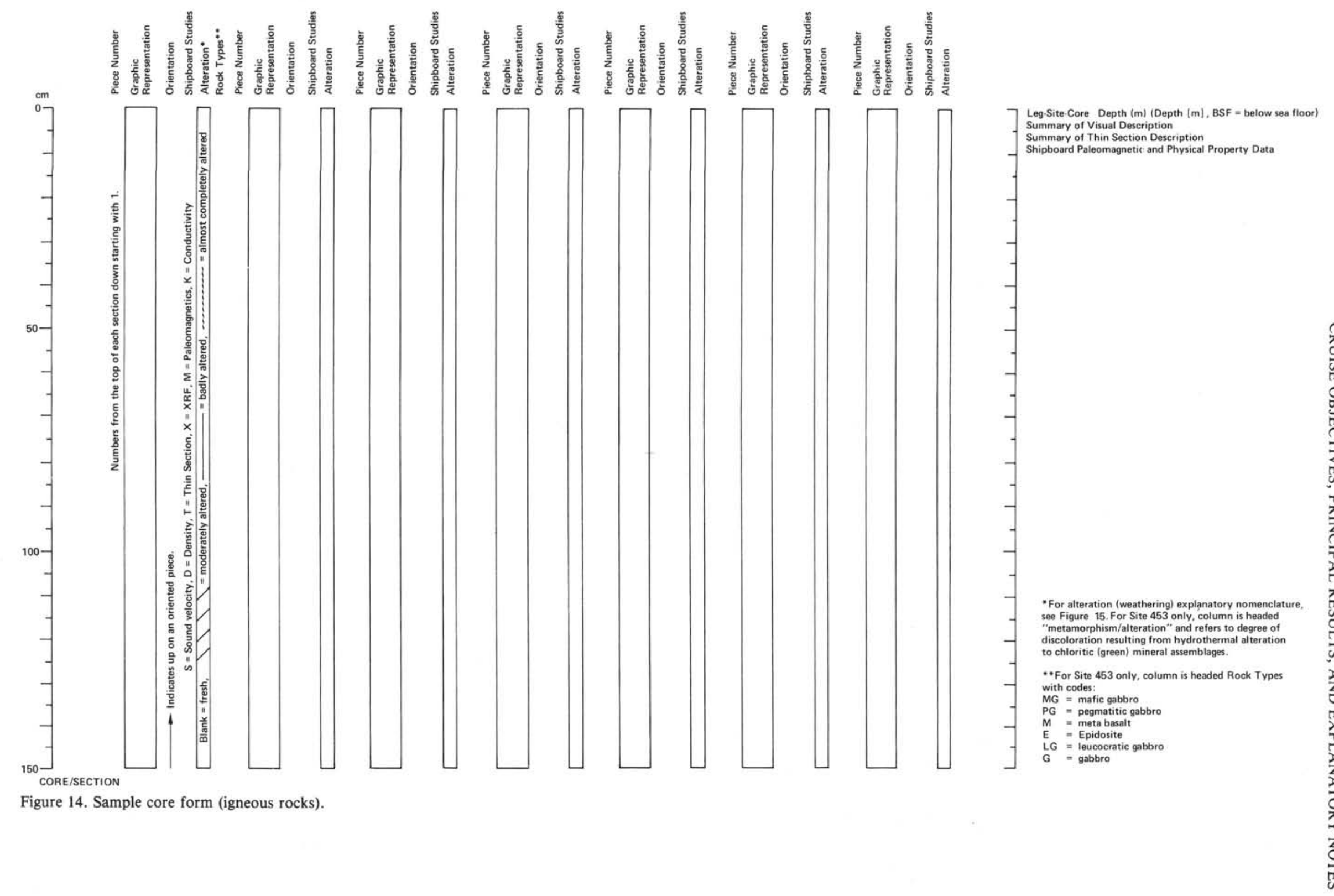

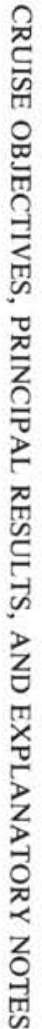


D. M. HUSSONG ET AL.

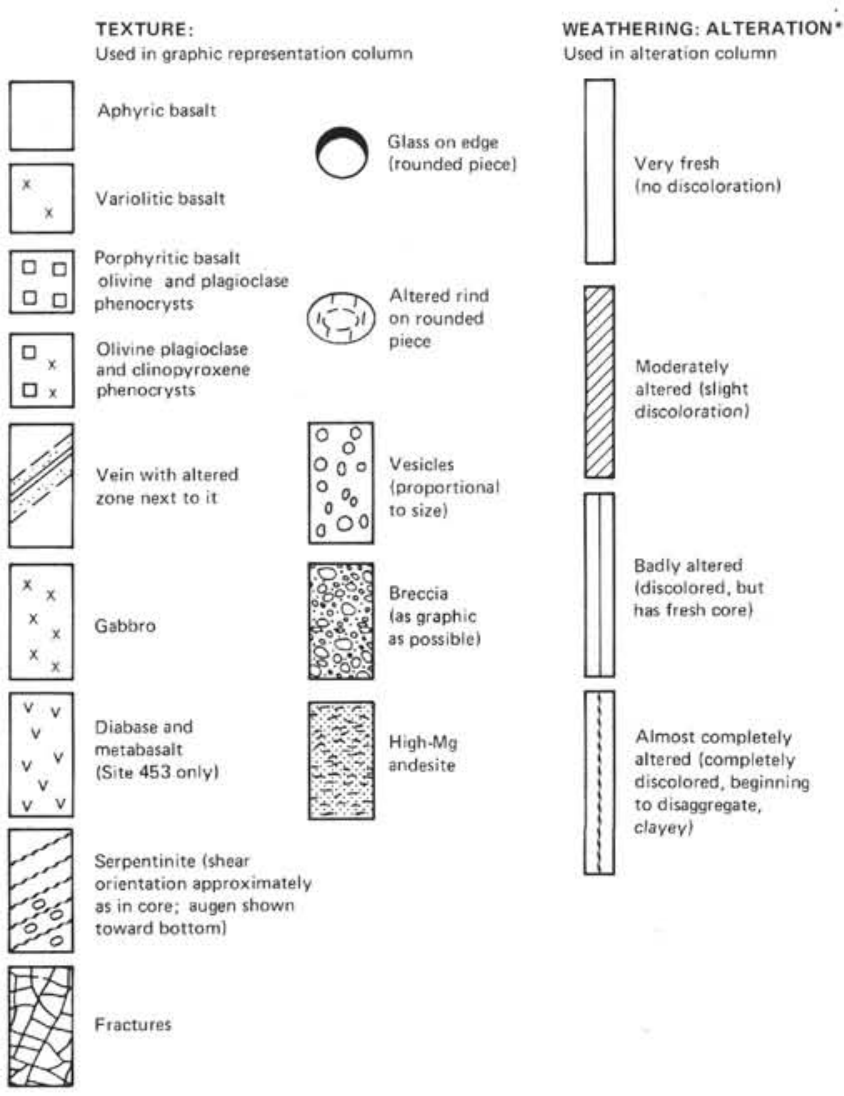

Figure 15. List of symbols, igneous and metamorphic rocks, Leg 60 (see note on Fig. 14). 